\title{
Classification of geothermal systems in Madagascar
}

\author{
M. Rajaobelison ${ }^{1 *}$, J. Raymond ${ }^{1}$, M. Malo ${ }^{1}$ and C. Dezayes ${ }^{2}$
}

\author{
*Correspondence: \\ miora_mirah. \\ rajaobelison@ete.inrs.ca; \\ rajaobmira@gmail.com \\ ${ }^{1}$ INRS-Institut National de la \\ recherche scientifique, 490 \\ de la Couronne, Quebec, QC \\ G1K 9A9, Canada \\ Full list of author information \\ is available at the end of the \\ article
}

\begin{abstract}
Classification schemes for geothermal energy sources have recently been improved to include the concept of geothermal play. Our comprehensive review for the island of Madagascar aims to enhance the understanding of the factors controlling the country's geothermal energy sources. The result is the first catalogue of geothermal systems in Madagascar. The geothermal systems of six prospective areas were categorized into three classes using the geological and tectonic context combined with the temperature of the potential geothermal reservoir. The three classes are (1) graben border-fault liquid-dominated moderate-temperature (Ambilobe and Miandrivazo areas), (2) fossil magmatic liquid-dominated moderate-temperature (Ambanja, Itasy and Antsirabe areas), and (3) sedimentary liquid-dominated low-temperature (Morondava Basin). The hydrothermal resources of Madagascar are commonly associated with extensional domains referred to as geothermal plays. A conceptual model was developed for each prospective area to better understand the factors controlling the heat source, formation permeability and fluid migration. Our results can be used to guide exploration strategies and have implications for assessing and quantifying Madagascar's geothermal potential.
\end{abstract}

Keywords: Geothermal energy, Geothermal play, Hydrothermal, Rift, Madagascar

\section{Introduction}

The first investigation into the geothermal potential of Madagascar was compiling an inventory of the hot springs (Besairie 1959), which was followed two decades later by an assessment of the geochemical characteristics of geothermal energy sources using chemical and isotopic analysis and chemical geothermometers on samples of hot spring water (Gunnlaugsson et al. 1981). The results provided a general characterization of the geothermal regions of Madagascar (Andrianaivo 2011). The prospective areas in this study have been subject to geological assessments, including structural geology (Andrianaivo and Ramasiarinoro 2010a, b). Knowing that geothermal exploration in Madagascar is at an early stage and that there is currently no geothermal power production in the country, this study reviews the available results from previous work with the objective to better understand the factors affecting the geothermal energy source and to produce the first catalogue of geothermal systems in Madagascar. The aim of the classification is to highlight the dominant characteristics of each area.

(c) The Author(s) 2020. This article is licensed under a Creative Commons Attribution 4.0 International License, which permits use, sharing adaptation, distribution and reproduction in any medium or format, as long as you give appropriate credit to the original author(s) and the source, provide a link to the Creative Commons licence, and indicate if changes were made. The images or other third party material in this article are included in the article's Creative Commons licence, unless indicated otherwise in a credit line to the material. If material is not included in the article's Creative Commons licence and your intended use is not permitted by statutory regulation or exceeds the permitted use, you will need to obtain permission directly from the copyright holder. To view a copy of this licence, visit http://creativeco mmons.org/licenses/by/4.0/. 
A 'geothermal system' in the hydrothermal regime can be described schematically as "convecting water in the upper crust of the Earth, which, in a confined space, transfers heat from a heat source to a heat sink, usually the free surfaces" (Hochstein 1990). According to this definition, the geothermal system comprises three main elements: a heat source, a permeable formation and a fluid, which is the heat carrier transferring thermal energy (Dickson and Fanelli 2003). A geothermal system can also be defined as "all parts of the hydrological system involved, including the recharge zone, all subsurface parts and the outflow of the system" (Axelsson 2008). Moreover, Williams et al. (2011) propose a broader definition that encompasses resources outside the hydrothermal regime: "any localized geologic setting where portions of the Earth's thermal energy may be extracted from a circulating fluid and transported to a point of use". Taking into account these definitions, it is important not to confuse the classification of geothermal systems with associated geothermal resources as the geothermal resources can be located in almost every geosystem but is not located everywhere in a geosystem. In addition, the definition of 'resources' has been considerably refined when referring to a 'geothermal energy source' in the terminology adopted by the United Nations Framework Classification for Resources (UNFC; Falcone et al. 2016), and can be classified according to the geothermal reservoir temperature (Muffler and Cataldi 1978; Hochstein 1990; Sanyal 2005), the dominant physical state of the fluids (White 1973; Nicholson 1993), and the enthalpy (Dickson and Fanelli 2003) and exergy of the geothermal fluids (Lee 2001). Moreover, the distribution of the geothermal energy source is controlled by geological and tectonic contexts (Armstead 1973; Muffler 1975). Erdlac et al. (2008) presented five key parameters that must be defined for a geothermal classification system to be considered appropriate: the geologic environment, the geological features or structural setting, the crustal "heat source", the resource category (specifically, "the medium within which the heat is to be found and produced"), and the rock type hosting the geothermal energy source.

In light of the above, the classification of geothermal systems must consider all the aspects of the geothermal energy source in a consistent manner. According to Moeck (2014), the critical element in the characterization, assessment and development of geothermal systems is the type of geothermal energy source. The more explicit the classification, the better and more practical the overview of the geothermal energy source types for defining their utilization and anticipating the heat transfer mechanisms allowing production. Moreover, recent advances in the geothermal play concept in which the type is based on geologic criteria have allowed geothermal systems to be grouped and separated according to their geologic characteristics and heat transport mechanisms to establish a catalogue of geothermal play types at the global or regional scale (Moeck 2014, 2018; Moeck et al. 2015, 2019; Schintgen et al. 2019). Thus, the limiting issue in geothermal system classification is not only the lack of available data but also the quality, which is dependent on the stage of geothermal exploration. Therefore, multiple authors have proposed classifications based on the following: (A) the reservoir equilibrium state, which can be dynamic or static based on the circulation of the reservoir fluid and whether the dominant mechanism of heat transfer is conduction or convection (Nicholson 1993); (B) fluid temperature and enthalpy combined with the corresponding dominant physical state (Sanyal 2005; Axelsson 2008); (C) the thermofacies concept, which classifies systems as petrothermal or hydrothermal based on the thermohydraulic characterization 
of rock units and the correlation between the petrophysical properties of the bedrock (permeability, thermal conductivity), their lithostratigraphic facies and the mechanism of heat transfer (Sass and Götz 2012); and (D) the anticipated technological means for developing the system, which distinguishes enhanced geothermal systems (EGS; Gallup 2009).

For the initial geothermal assessment of a region, classifying the geothermal systems is one of the key elements to start the characterization, evaluation and development of geothermal energy sources (Williams et al. 2011). In this sense, the information should be organized to highlight and identify the value of particular data, especially geological settings and subsurface temperature. Geological settings are often critical in the assessment and exploration of geothermal energy sources as they can be used to anticipate the system's utilization and potential production mechanisms. In addition, a detailed understanding of surface geological settings can help improve geothermal system classification for use in decision-making at the pre-drilling phase of exploration. This type of classification is, in fact, a low-cost tool, providing reliable cataloguing data applicable to site-specific field development.

This work is the first attempt to develop a catalogue of geothermal systems in Madagascar. The classification is primarily based on the identification of geological settings combined with the available data, including the temperature of geothermal reservoirs inferred from chemical geothermometers. Our work generally follows the alternative scheme proposed by Moeck (2014), which introduces geothermal play types, because we believe it better describes the characteristics of the geothermal system classes found in Madagascar. Our study conceives conceptual models for each class in selected prospective areas. The proposed classification and associated conceptual models represent one step in organizing the existing information in a manner that makes it useful as a guide in decision-making processes. The proposed classification should be seen as a starting point rather than an end product as it can be improved for each region once more subsurface data become available.

\section{Geographical and geological settings}

Madagascar is the largest island situated in the Indian Ocean, separated from Africa by the Mozambican Channel. The geology of Madagascar is characterized by a Precambrian shield composed of Archaean to Proterozoic magmatic and metamorphic rocks, which are exposed in the eastern two-thirds of the island (Fig. 1a). This Precambrian basement was remarkably reworked by several intense tectonic and orogenic processes during the Neoproterozoic Pan-African orogeny between 600 and 800 Ma (Windley et al. 1994; De Wit 2003). It is divided into six main tectono-metamorphic domains, namely Vohibory, Bemarivo, Ikalamavoina, Androy-Anosyan and Antananarivo (De Wit 2003; Collins 2006; Tucker et al. 2014), and separated from each other by tectonic contacts comprising ductile high-strain or shear zones (Giese et al. 2011; Tucker et al. 2014).

The remaining third of the island, along its western side, is covered by extensive sedimentary basins (Fig. 1a). From north to south, the three main basins are Ambilobe (Diego), Mahajanga and Morondava. There are also smaller basins along the eastern coast. These basins preserve a nearly complete record of deposits from Upper Carboniferous to Mid-Jurassic, which are the equivalent of the Gondwana sequences in India and 


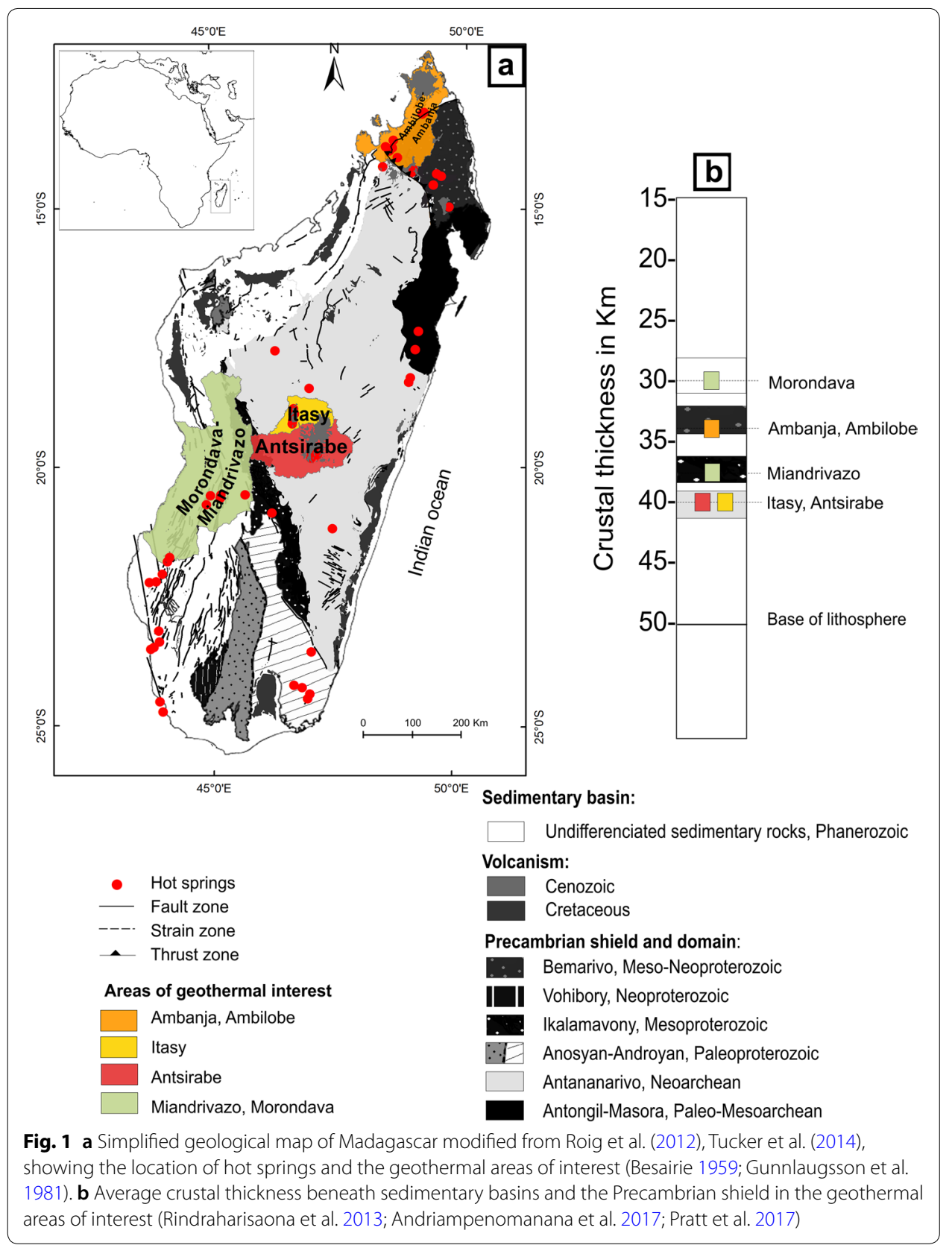

the Karoo sequences in Africa. In Madagascar, these deposits are divided into the Sakoa, Sakamena and Isalo groups (Besairie 1952), overlain by quaternary to recent unconsolidated sediments.

The sedimentary basins and associated structures formed in response to aborted Permo-Triassic Karoo rifting and the subsequent separation from Eastern Africa in the Jurassic and from India in the Cretaceous (Razafimbelo 1987; Piqué et al. 1999a, b). The latter initiated late Cretaceous volcanism (Rasamimanana et al. 1998; Bardintzeff et al. 2010), predominantly along the western, southern and eastern margins of the island (Fig. 1a). The Jurassic rifting of Madagascar from Eastern Africa is also responsible for the thinning of the crust beneath the basins, which averages $30 \pm 5 \mathrm{~km}$ thick, including 
2 to $8 \mathrm{~km}$ of sedimentary rocks (Andriampenomanana et al. 2017; Rindraharisaona et al. 2017). However, the Neogene to quaternary tectonic reactivation resulted in renewed Cenozoic volcanic activity in the central region (Rufer et al. 2006), as well as in the northern part where numerous alkaline intrusions are associated with extensional faults of Plio-Quaternary (Chorowicz et al. 1997; Cucciniello et al. 2016) and early Tertiary age (Rossi 1980). The Moho is found at an average depth of $40 \mathrm{~km}$ and $33 \mathrm{~km}$ in the central and northern regions, respectively (Andriampenomanana et al. 2017). The lithosphere of Madagascar is encountered at an average depth of $50 \mathrm{~km}$ (Fig. 1b). Serval authors (Wysession et al. 2016; Andriampenomanana et al. 2017; Paul and Eakin 2017; Pratt et al. 2017) have assumed that the lithosphere has been significantly modified beneath the northern, central and southwestern regions of the island where major Cenozoic volcanic provinces and uplift are present (Roberts et al. 2012).

Six different areas in various parts of Madagascar have been identified as interesting geothermal prospectives (Fig. 1): Ambilobe and Ambanja (North), Itasy and Antsirabe (Central), and Miandrivazo and Morondava (West). Studies from the 1980s used geothermometer analysis to demonstrate that these areas have an expected geothermal reservoir temperature between 120 and $240{ }^{\circ} \mathrm{C}$ (Gunnlaugsson et al. 1981; Sarazin et al. 1986). The development of geothermal energy sources, primarily for electricity production and other direct uses (Andrianaivo 2011), can benefit these regions where electricity is currently supplied by hydropower and imported fossil fuels, and where economy is based essentially on agriculture, trade and mining. In this study, we have focused on these six areas to better qualify and understand the geothermal energy source potential.

\section{Development of a geothermal system classification}

In this work, the geothermal systems in the six areas of interest are classified using a combination of different criteria, such as the geological setting, the potential geothermal reservoir temperature and the dominant physical state of the fluids. The data in published literature were reviewed, and the following steps were followed to establish the geothermal system classification.

1. The first step consisted of characterizing the geological environment by highlighting the tectonic and structural settings at the regional scale in each area. The analysis of tectonic data was based on up-to-date geological maps and the available literature for the tectono-metamorphic domains of Madagascar (Fig. 1). This information was then used to infer the dominant geologic control on fluid flow or the heat migration pathway, geothermal play type and heat source. These elements were used to develop the catalogue of geothermal systems in Madagascar, similar to the manner proposed by Erdlac (2011) for classifying geothermal energy sources in a geothermal power classification system and by Moeck $(2014,2018)$ and Moeck et al. (2015) for cataloguing geothermal plays.

2. The second step was to study the geothermal characteristics of Madagascar's geothermal areas in relation to their geological setting. The predominant geological formations identified in the prospective areas include trap formations or cap rocks that limit the escape of heat, as well as host rocks from which geothermal energy source can potentially be extracted. The results of hot spring analyses and geothermometer 
studies were used to deduce the dominant mobile phase of fluids in the deep geothermal reservoir using the classification proposed by Sanyal (2005). This means all low-temperature systems are considered liquid-dominated, the moderate-temperature systems are almost exclusively liquid-dominated, and the high-temperature systems include both liquid- and vapour-dominated resources.

3. The third and last step was to identify the relevant geothermal systems and classify them by heat source type according to their geological environment, followed by the physical state of the mobile fluid phase based on the estimated geothermal reservoir temperature (Table 1; Rezaie and Aghajani 2013). Three qualifiers (low, moderate or high) are used for the temperature range of the geothermal reservoir based on the work of Sanyal (2005), who set the range for low to moderate at $150-230{ }^{\circ} \mathrm{C}$, and for moderate to high at $190-300{ }^{\circ} \mathrm{C}$.

As a basis for discussion, prospect areas arising from this classification were compared to global analogue regions that have similar geothermal characteristics, but where a more advanced stage of geothermal development exists.

\section{Classes of geothermal systems}

Before assigning a class to the studied geothermal systems, the prospective areas were first characterized in terms of tectono-metamorphic domain, geological system or plate tectonic setting, geothermal play type and heat source (Table 2). They were then characterized by geological formation and geothermal characteristics (Table 3). Finally, the prospective areas were assigned to three classes of geothermal system, as defined in Table 4.

As outlined in Table 2, the geological formations of the six prospective areas can be grouped by the tectono-metamorphic domain. The Ambilobe and Ambanja areas are part of the Bemarivo Domain. The Itasy and Antsirabe areas belong to the Antananarivo Domain. The Miandrivazo area is in the Ikalamavony Domain and the Morondava area is in the Morondava Basin. Each area is also characterized by its geologic system or plate tectonic setting, which are sedimentary-basement fault boundary, graben, pull-apart basin, and passive margin basin. The geothermal play-an extensional domain-is the same for all the prospective areas. Thus, faults and fractures control the fluid migration pathway. Most of the faults with N-S, NNE-SSW and NNW-SSE trends are related to Cenozoic volcanism in Madagascar (Rasamimanana 1996; Melluso and Morra 2000; Rufer et al. 2006). The more ancient faults were reactivated during the crustal extension between Madagascar and Africa, which restarted in Miocene times and continued during the Pliocene and Quaternary. Those faults are still active today (Rasamimanana 1996; Bertil and Marc 1998; Piqué et al. 1999a, b).

Table 1 Example of the geothermal system classification for Madagascar

\begin{tabular}{llll}
\hline & $\begin{array}{l}\text { Geological setting/heat } \\
\text { source } \\
\text { Graben border-fault/ } \\
\text { Shallow Moho }\end{array}$ & $\begin{array}{l}\text { Dominant physical state } \\
\text { of the mobile fluid phase } \\
\text { Liquid-dominated }\end{array}$ & $\begin{array}{l}\text { Temperature } \\
\text { of geothermal reservoir } \\
\text { Moderate }\end{array}$ \\
\hline $\begin{array}{l}\text { Classification of geother- } \\
\text { mal system }\end{array}$ & Graben border-fault liquid-dominated moderate-temperature \\
\hline
\end{tabular}


Table 2 Geological and tectonic controls for prospective areas in Madagascar

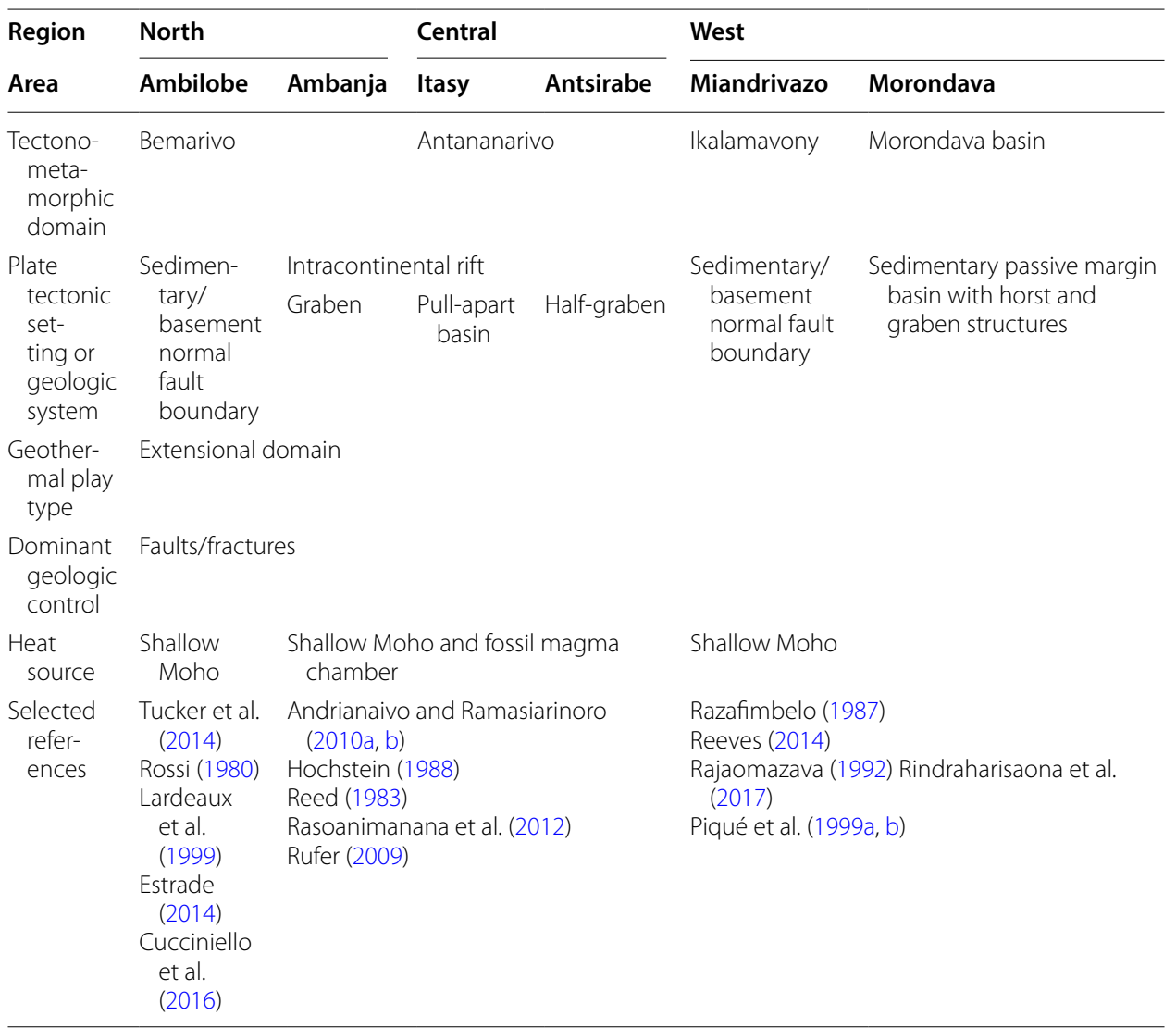

Although these geothermal areas are situated in the volcanic provinces of the North (Ambanja and Ambilobe) and Central regions (Itasy an Antsirabe), this volcanism is old and considered to be a fossil system. The latest volcanic activity is Miocene to Pleistocene in age, 17 to $1.8 \mathrm{Ma} \pm 0.13$ and 28 to $3 \mathrm{Ma}$, respectively (Bardintzeff et al. 2010; Estrade et al. 2014). The magmatism related to volcanism is considered to be extinct, up to 50,000-year old, according to McCoy-West et al. (2011). The isotopic and trace-element composition of the basalts from these volcanic provinces indicates that the deep source of the related magma was derived from the lower part of the lithospheric mantle (Bardintzeff et al. 2010). Therefore, even if fossil magma chambers exist, they cannot be considered the main source of heat. However, the extensional tectonics and the crustal thinning below these volcanic provinces, where the average thickness is 33-40 km (Andriampenomanana et al. 2017), correspond to regions of upwelling asthenosphere (Wysession et al. 2016; Pratt et al. 2017), the origin of the heat source. In the Miandrivazo area and the Morondava sedimentary basin, magmatism occurred during the Cretaceous and did not constitute the heat source.

Table 3 highlights the predominant geological formations of the geothermal areas, including the potential host rocks containing the geothermal energy source or hot fluids, the range of temperature for the hot springs, the range of temperature at depth, the dominant chemical composition of the fluids, and the main mobile phase. For 
Table 3 Geological and geothermal characteristics for prospective areas in Madagascar

\begin{tabular}{|c|c|c|c|c|c|c|c|}
\hline \multirow{2}{*}{$\begin{array}{l}\text { Region } \\
\text { Area }\end{array}$} & \multicolumn{2}{|l|}{ North } & \multicolumn{2}{|l|}{ Central } & \multicolumn{2}{|l|}{ West } & \multirow[t]{2}{*}{ Source } \\
\hline & Ambilobe & Ambanja & Itasy & Antsirabe & Miandrivazo & Morondava & \\
\hline $\begin{array}{l}\text { Dominant } \\
\text { geologi- } \\
\text { cal forma- } \\
\text { tions }\end{array}$ & $\begin{array}{l}\text { Sandstone } \\
\text { and shale } \\
\text { of the } \\
\text { Isalo and } \\
\text { Saka- } \\
\text { mena } \\
\text { groups }\end{array}$ & $\begin{array}{l}\text { Paragneiss } \\
\text { and mig- } \\
\text { matite of } \\
\text { the Sam- } \\
\text { birano } \\
\text { Group }\end{array}$ & \multicolumn{2}{|c|}{$\begin{array}{l}\text { Migmatitic gneiss, } \\
\text { paragneiss and schist } \\
\text { of the Ambatolampy } \\
\text { Group }\end{array}$} & $\begin{array}{l}\text { Orthogneiss } \\
\text { and ton- } \\
\text { alitic-granite } \\
\text { of the Dab- } \\
\text { olava Suite }\end{array}$ & $\begin{array}{l}\text { Sandstone, } \\
\text { limestone, } \\
\text { clay and } \\
\text { marl of } \\
\text { the Isalo, } \\
\text { Sakamena } \\
\text { groups }\end{array}$ & $\begin{array}{l}\text { Interpreted } \\
\text { from } \\
\text { geologi- } \\
\text { cal maps }\end{array}$ \\
\hline $\begin{array}{l}\text { Tempera- } \\
\text { ture of } \\
\text { hot } \\
\text { springs } \\
\left({ }^{\circ} \mathrm{C}\right)\end{array}$ & $47-78$ & $48-72$ & $24-57$ & $38-57$ & $30-55$ & $39-42$ & $\begin{array}{l}\text { Hambinint- } \\
\text { soa et al. } \\
\text { (2017) } \\
\text { Gunnlaugs- } \\
\text { son et al. } \\
\text { (1981) } \\
\text { Besairie } \\
\text { (1959) }\end{array}$ \\
\hline $\begin{array}{l}\text { Tempera- } \\
\text { ture of } \\
\text { geother- } \\
\text { mometer } \\
\left({ }^{\circ} \mathrm{C}\right)\end{array}$ & 140-180 & $140-200$ & $170-240$ & $150-240$ & $140-170$ & $120-140$ & $\begin{array}{l}\text { Gunnlaugs- } \\
\text { son et al. } \\
\text { (1981) }\end{array}$ \\
\hline $\begin{array}{l}\text { Dominant } \\
\text { chemical } \\
\text { composi- } \\
\text { tion of } \\
\text { fluids }\end{array}$ & \multicolumn{2}{|c|}{$\begin{array}{l}\text { Moderate to high } \mathrm{CO}_{2} \\
(200-1000 \mathrm{ppm}) \text { and } \\
\text { low } \mathrm{Cl}(<300 \mathrm{ppm})\end{array}$} & \multicolumn{2}{|c|}{$\begin{array}{l}\text { High } \mathrm{CO}_{2}(1000- \\
4000 \mathrm{ppm}) \text { and } \mathrm{Cl} \\
(400-500 \mathrm{ppm})\end{array}$} & \multirow{2}{*}{\multicolumn{2}{|c|}{$\begin{array}{l}\text { Low } \mathrm{CO}_{2}<200 \mathrm{ppm} \text { and mod- } \\
\text { erate } \mathrm{Cl}(500-1200 \mathrm{ppm}) \\
\text { Saline brine, NaCl-dominated } \\
\text { Basinal or infiltration fluids? }\end{array}$}} & $\begin{array}{l}\text { Hambinint- } \\
\text { soa et al. } \\
\text { (2017) } \\
\text { Gunnlaugs- } \\
\text { son et al. } \\
\text { (1981) }\end{array}$ \\
\hline $\begin{array}{l}\text { Mobile fluid } \\
\text { phase in } \\
\text { the geo- } \\
\text { thermal } \\
\text { reservoir }\end{array}$ & \multicolumn{4}{|c|}{ Liquid-dominated } & & & $\begin{array}{l}\text { Interpreted } \\
\text { according } \\
\text { to tem- } \\
\text { perature } \\
\text { of geo- } \\
\text { thermal } \\
\text { reservoir }\end{array}$ \\
\hline
\end{tabular}

Table 4 Geothermal system classes for prospective areas in Madagascar

\begin{tabular}{|c|c|c|c|c|c|}
\hline \multirow{2}{*}{$\begin{array}{l}\text { Region } \\
\text { Area }\end{array}$} & \multicolumn{2}{|l|}{ North } & Central & \multicolumn{2}{|l|}{ West } \\
\hline & Ambilobe & Ambanja & Antsirabe & Miandrivazo & Morondava \\
\hline $\begin{array}{l}\text { Geological } \\
\text { environment } \\
\text { and heat } \\
\text { source }\end{array}$ & $\begin{array}{l}\text { Graben border- } \\
\text { fault } \\
\text { Shallow Moho }\end{array}$ & $\begin{array}{l}\text { Graben } \\
\text { Shallow } \\
\text { Moho } \\
\text { and fossil } \\
\text { magma } \\
\text { chamber }\end{array}$ & $\begin{array}{l}\text { Volcanic } \\
\text { Shallow Moho and fossil } \\
\text { magma chamber }\end{array}$ & $\begin{array}{l}\text { Graben } \\
\text { border-fault } \\
\text { Shallow Moho }\end{array}$ & $\begin{array}{l}\text { Sedimentary } \\
\text { Shallow Moho }\end{array}$ \\
\hline $\begin{array}{l}\text { Physical } \\
\text { state of the } \\
\text { mobile fluid } \\
\text { phase }\end{array}$ & \multicolumn{5}{|c|}{ Liquid-dominated } \\
\hline Fluid enthalpy & Moderate & & & & Low \\
\hline Class & $\begin{array}{l}\text { Graben border- } \\
\text { fault liquid- } \\
\text { dominated } \\
\text { moderate- } \\
\text { temperature }\end{array}$ & \multicolumn{2}{|c|}{$\begin{array}{l}\text { Fossil-magmatic liquid-dominated } \\
\text { moderate-temperature }\end{array}$} & $\begin{array}{l}\text { Graben } \\
\text { bounder- } \\
\text { fault liquid- } \\
\text { dominated } \\
\text { moderate- } \\
\text { temperature }\end{array}$ & $\begin{array}{l}\text { Sedimentary } \\
\text { liquid-dom- } \\
\text { inated low- } \\
\text { temperature }\end{array}$ \\
\hline
\end{tabular}


all six areas, the Precambrian to Cambrian basement is dominated by paragneiss, orthogneiss and schists. In Ambilobe and Morondava, the Permian to Triassic sedimentary units that overlie the basement comprise sandstone, shale, clay, and limestone marls belonging to the Karoo Supergroup sequence. These rock units can be considered for geothermal exploration. According to the chemical geothermometer analysis conducted by Gunnlaugsson et al. (1981), the predicted geothermal reservoir temperature is in the range of $140-180{ }^{\circ} \mathrm{C}$ for the Ambilobe area, $140-200{ }^{\circ} \mathrm{C}$ for Ambanja, $170-240{ }^{\circ} \mathrm{C}$ for Itasy, $150-240{ }^{\circ} \mathrm{C}$ for Antsirabe, $140-170{ }^{\circ} \mathrm{C}$ for Miandrivazo, and below $150{ }^{\circ} \mathrm{C}$ for Morondava. According to Sanyal (2005), these expected reservoir temperatures indicate that the dominant mobile phase is liquid for the fluids in all six areas. The water chemistry of Ambilobe and Ambanja is characterized by moderate to high carbon dioxide concentration (200-1000 ppm $\mathrm{CO}_{2}$ ) with low chloride content $(<300 \mathrm{ppm} \mathrm{Cl})$. Water from Itasy and Antsirabe has a high carbon dioxide concentration, ranging between 1000 and $4000 \mathrm{ppm} \mathrm{CO}_{2}$, with moderate to low salinity and a chloride content of 400 to $500 \mathrm{ppm} \mathrm{Cl}$. Water from Miandrivazo and Morondava has low carbon dioxide concentration $\left(<200 \mathrm{ppm} \mathrm{CO}_{2}\right)$ and moderate chloride (500-1200 ppm Cl) and basinal characteristics, such as saline $\mathrm{NaCl}$-dominated brine.

Finally, as presented in Table 4, the three main geothermal systems defined for each area are

a. Graben border-fault liquid-dominated moderate-temperature systems for Ambilobe and Miandrivazo;

b. Fossil magmatic liquid-dominated moderate-temperature systems for Ambanja, Itasy and Antsirabe;

c. Sedimentary liquid-dominated low-temperature systems for Morondava.

\section{Conceptual models and geothermal system classes}

A conceptual model was prepared for the geothermal system identified for each prospective area based on the data in Tables 2, 3 and 4. Models are presented as interpreted $2 \mathrm{D}$ cross-sections on which the physical features of the system are drawn, including geological structures and fluid flow that is ultimately controlled by the geological structures (Hinz et al. 2016; Wallis et al. 2018). The models were developed following the approach reviewed by Axelsson (2013). They are descriptive or qualitative models built to better understand the factors controlling the heat source, formation permeability and fluid migration.

In this paper, the term 'host rock' identifies the dominant geological formations of the potential geothermal reservoir based on the information in Table 3. It should be noted that porosity and permeability data are often insufficient to properly define the geothermal reservoir potential of the host rocks. Given the early stage of geothermal exploration in Madagascar, the available information is mostly limited to surface exploration, such as geological and structural maps, as well as remote-sensing interpretations (Collins 2006; Roig et al. 2012; Tucker et al. 2014). Geophysical surveys and seismic data have provided a general understanding of the lithospheric structure of Madagascar (Wysession et al. 
2016; Paul and Eakin 2017), yielding information on the uppermost mantle, and the average thickness of the Madagascar crust, including the average thickness of the sedimentary rocks and crystalline basement (Andriampenomanana et al. 2017; Pratt et al. 2017; Rindraharisaona et al. 2017). The average thickness of sedimentary sequences varies from 2 to $6 \mathrm{~km}$ (Andriampenomanana et al. 2017; Rindraharisaona et al. 2017). For this reason, the conceptual models were drawn to a maximum depth of $5 \mathrm{~km}$.

\section{North region}

\section{Ambilobe area}

The Ambilobe area is located in a normal fault zone called Andavakoera, which delineates the contact between sedimentary sequences and basement rocks (Table 2). It forms a depression $120 \mathrm{~km}$ long and 3 to $5 \mathrm{~km}$ wide. It is oriented NE-SW in the direction of the major faults, which have cut the basement and sedimentary cover since the Triassic (Lardeaux et al. 1999). Undifferentiated NW-SE faults and strike-slip faults with dextral or sinistral movements are also observed (Fig. 2b). The latter are associated with recent E-W rifting that likely triggered the formation of the vast Neogene-Quaternary alkaline volcanic fields in the North and Central regions of Madagascar (Bertil and Marc 1998; Melluso and Morra 2000). An N-S cross-section has been drawn to represent the conceptual model (Fig. 2c).

The sedimentary sequence unconformably overlying the Neoproterozoic metamorphic bedrock is part of the Ambilobe Basin. It consists of Permian sandstones and

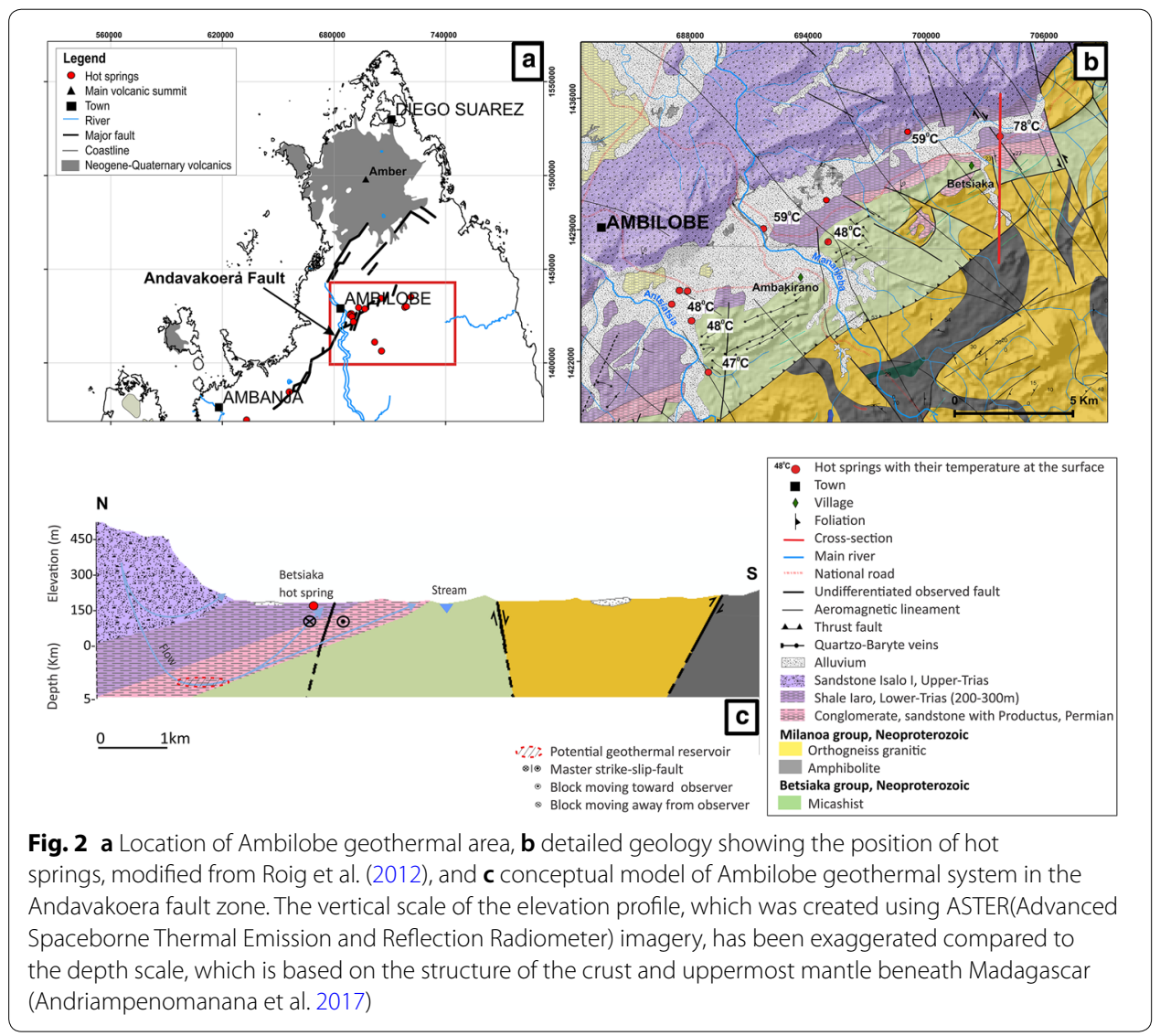


conglomerates, which are covered by Eotriasic shales of the Sakamena Group and Upper Triassic sandstones of the Isalo Groups which are also called Isalo I. The latter overlies either Permo-Triassic deposits or Neoproterozoic basement. The sandstones of Isalo I group form an imposing escarpment 400 to $500 \mathrm{~m}$ high along a depression dipping 5 to $30^{\circ}$ to the northwest. Metre-scale quartzo-barytic veins and faults, having the same $\mathrm{N} 050^{\circ} \mathrm{E}$ to $\mathrm{N} 150^{\circ} \mathrm{E}$ strike, intersect the sediment cover as well as the basement. Recent alluvial deposits are found in the depression on top of the Ambilobe basin sequence. The Neoproterozoic basement is predominantly mica schist of the Betsiaka Group and muscovite-amphibole orthogneiss and garnet-amphibolite of the Milanoa Group (Fig. 2b), which stabilized in the greenschist and amphibolite metamorphic facies (Thomas et al. 2009; Tucker et al. 2014).

Thermal water mainly emerges along the NE-SW direction of the depression through fractures cutting the shale unit, such as the hot springs near the villages of Ambakirano and Betsiaka (Fig. 2b). These hot springs likely originate in the Permian or Triassic sandstones, believed to be possible host rocks, whilst the Eotriassic shales are potential cap rocks (Table 3). Following the general topography, the fluids are thought to circulate from north to south, as shown on the conceptual model (Fig. 2c). At the surface, the springs in the villages reach temperatures of 59 and $72{ }^{\circ} \mathrm{C}$, respectively. According to chemical geothermometers (Gunnlaugsson et al. 1981), the geothermal reservoir temperature can be 140 to $180{ }^{\circ} \mathrm{C}$ (Table 3). The carbon dioxide concentration of the hot spring water is moderate to high (from 200 to $4000 \mathrm{ppm}$ ), which can cause calcite scaling and corrosion during geothermal exploitation (Gunnlaugsson et al. 1981).

The average thickness of the crust in the Ambilobe area is $33 \mathrm{~km}$, including an average of $4 \mathrm{~km}$ of sedimentary rocks (Andriampenomanana et al. 2017; Pratt et al. 2017), forming a potential thermal blanket that could help induce a geothermal gradient steeper than $35^{\circ} \mathrm{C} / \mathrm{km}$, which is considered moderate in this study. Recent magmatism occurred from 14 Ma to $0.83 \mathrm{Ma}$ (Buchwaldt 2006) and has been described by Estrade (2014). The main volcanic massif in the North region, known as the Amber Massif, is located about $50 \mathrm{~km}$ from the Ambilobe area (Fig. 1a). Thus, the Ambilobe heat source is mainly attributed to the thinning of the crust in an extensional structural setting.

\section{Ambanja area}

The Ambanja area is characterized by a $25-\mathrm{km}$-long graben-oriented NW-SE direction with an average width of $4 \mathrm{~km}$ (Table 2, Fig. 3b). The timing of the brittle tectonic activity that generated the Sambirano Graben is not exactly known, but most probably formed during the early Tertiary, before the first Miocene volcanic eruptions in this area, as suggested by Rossi (1980), with major reactivation until the Quaternary (Mottet 1982). The graben formed in Proterozoic basement units, predominantly composed of paragneiss belonging to the Sambirano Group. The depression was filled with detrital and alluvial sediments. Permo-Trias sandstones and shale successions appear only in the northwest. Basalts and basanites are found in the eastern part of the graben, whilst ignimbrites have been observed mostly in the southern part. The volcanic deposits, between 600 and $700 \mathrm{~m}$ thick, include lapilli and tuff overlying ignimbrites. These volcanic deposits originated from the neighbouring stratified volcanic complexes of the Tsaratanana Massif. 


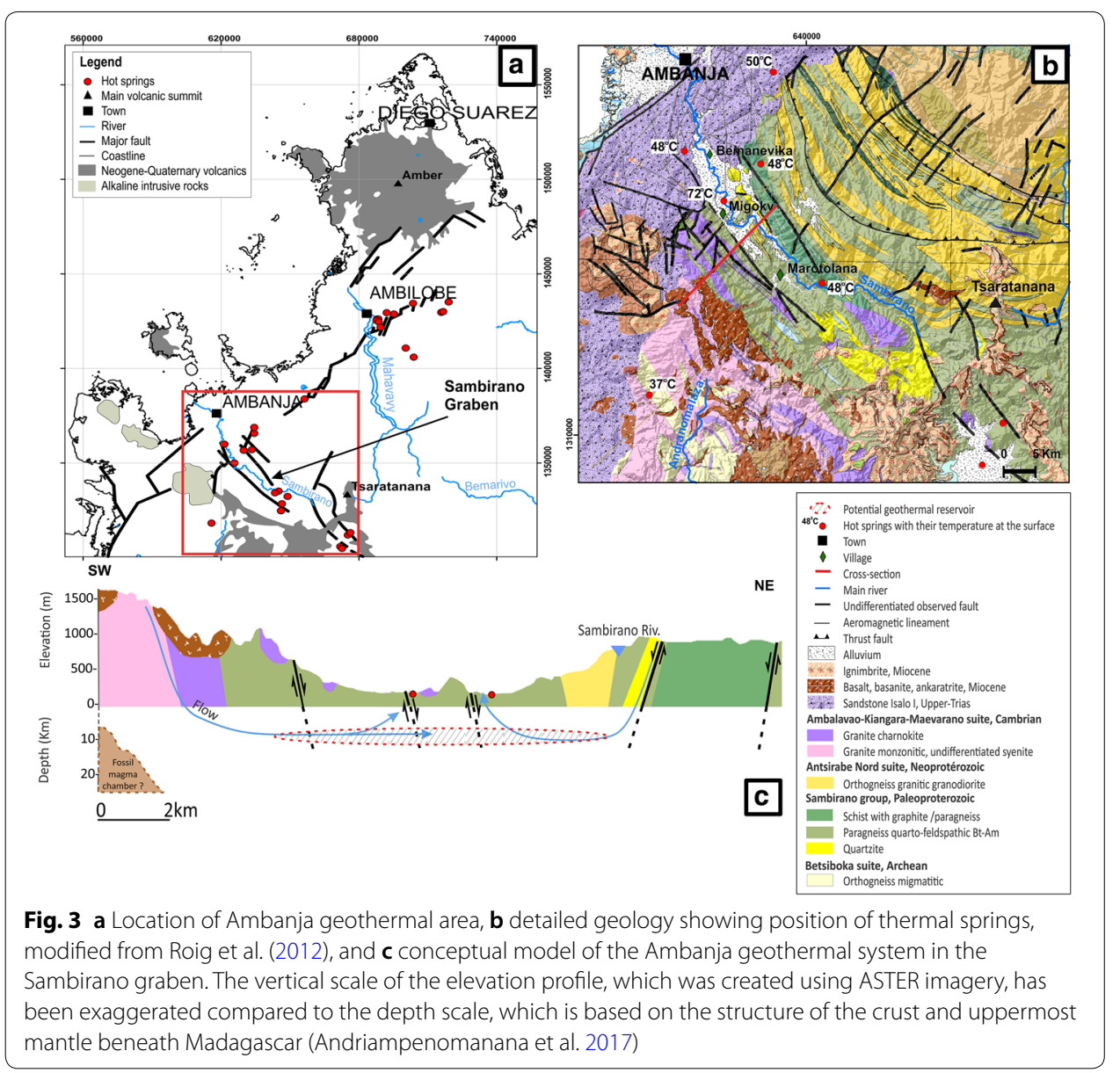

Hot springs emerge mostly along the NW-SE-striking fractures and faults bounding the graben (Fig. 3b). Our conceptual model proposes that NW-SE graben faults, with currently unknown depth, can be a potential path for subsurface flow. Fluids circulate mainly from SW to NE and from NE to SW on both sides of the valley. This interpretation is consistent with the topography, where recharge occurs along topographic highs, and water flows towards valleys with a lower altitude (Fig. 3c). There is no evidence that porous units can form permeable host rocks as in the Ambilobe area. The host rocks are thought to be fractured basement rocks (Table 3). The hot springs are located close to the faults and have a temperature of 48 to $72{ }^{\circ} \mathrm{C}$. Using chemical geothermometers, Gunnlaugsson et al. (1981) estimated that fluid temperature can reach 140 to $200{ }^{\circ} \mathrm{C}$ inside the geothermal reservoir, corresponding to a moderate enthalpy and a dominant liquid state. A low concentration of solids and dissolved gases were also observed (Table 3).

The period of magmatism giving rise to the alkaline intrusion observed in the northeastern part of the graben (Fig. 3a) is dated between 27 and $20 \mathrm{Ma}$, followed by a more recent volcanism period of 17 to $15 \mathrm{Ma}$ for the Tsaratanana Massif (Buchwaldt 2006), described by Estrade (2014). It can be assumed that a fossil magma chamber is possibly located beneath the Tsaratanana volcanic massif, which can be 
related to the origin of the alkaline intrusive complexes as shown in Fig. 3c. Therefore, the recent magmatism and the decay of radiogenic elements in recently crystallized rock may be providing additional heat to the heat originating from a shallow mantle in the Ambanja area. But the average crustal thickness and lithosphere depth, $30 \mathrm{~km}$ and $50 \mathrm{~km}$, respectively, are the same as in the Ambilobe area (Wysession et al. 2016; Andriampenomanana et al. 2017; Pratt et al. 2017). This shallow Moho depth is believed to be the most important heat source contributing the increase of geothermal gradient, which is expected to be moderate.

\section{Central region}

\section{Itasy area}

The Itasy area is one of the most seismically active volcanic regions in the central part of Madagascar, with earthquake magnitudes up to 4 (Rakotondrainibe 1977; Bertil and Marc 1998; Ramarolahy 2016). In this part of the country, Cenozoic volcanic deposits overlying the Precambrian basement form numerous domes (Upper Oligocene to Pleistocene), scoria cones and lava flows of trachytic to basanitic composition (Fig. 4b). The latter is predominantly composed of migmatitic gneiss belonging to the Antananarivo Domain (Tables 2 and 3). Magnetotelluric and magnetic surveys revealed that the Pleistocene volcanic deposits and lavas are only 50 to $100 \mathrm{~m}$ thick (Ratsimbazafy 1987). Geysers, travertine mounds and aragonite deposits are common landscape features. The conceptual model of the Itasy area is based on geological structures and regional

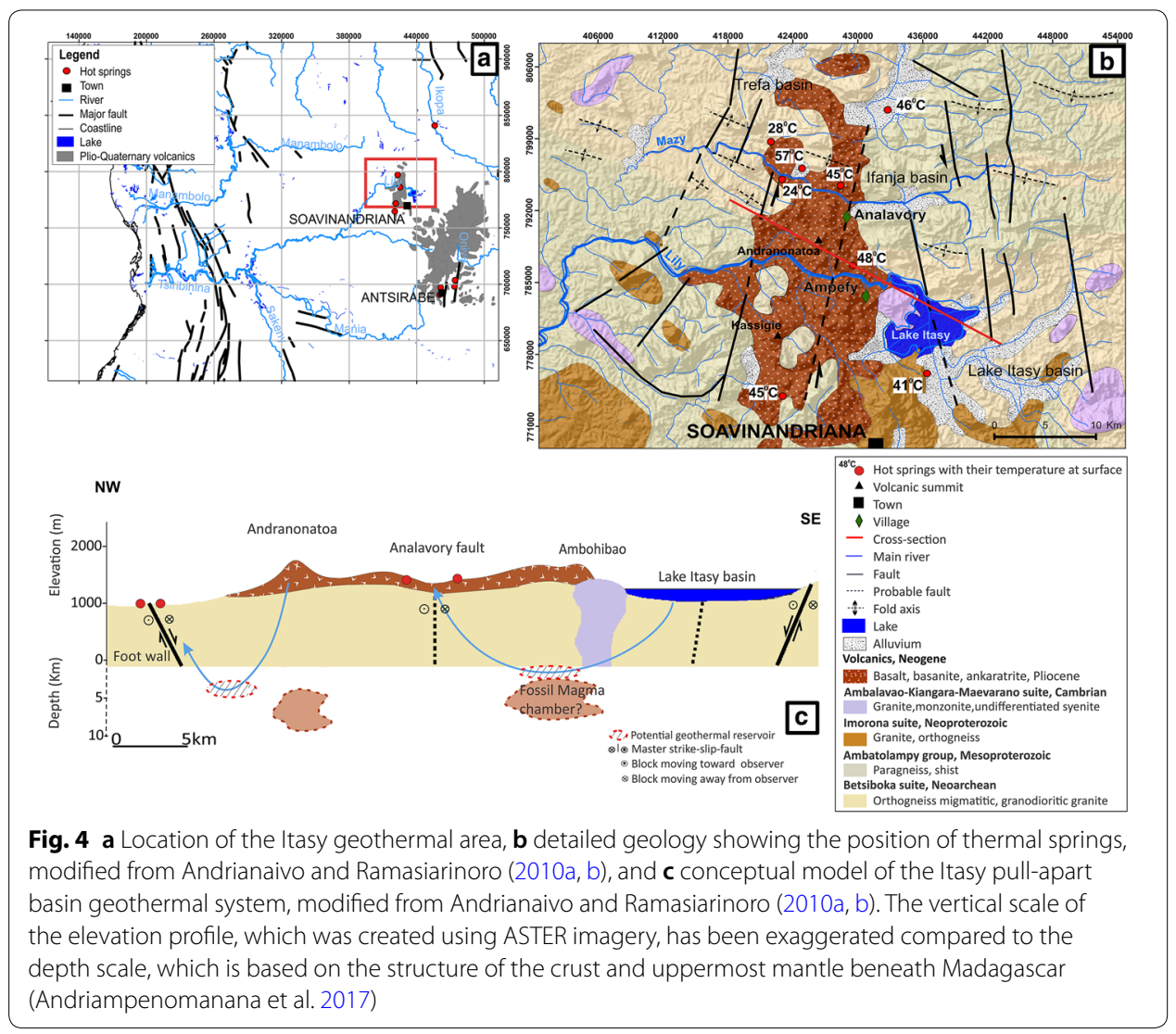


lineaments. Three small strike-slip basins-Trefa, Ifanja and Lake Itasy-were created by complex displacements along NNE strike-slip fault zones (Fig. 4b, c). These small basins are interpreted as pull-apart basins (Table 2) (Andrianaivo and Ramasiarinoro 2010a, b). Major N-S discontinuities, such as faults, suggest regional E-W extension. Active faulting is responsible for the seismicity in this region (Ramarolahy 2016).

In such transtensional geothermal systems, the hydrothermal flow paths are characterized by basinward-dipping faults, and the fluids are more likely to migrate along the pathways of hanging-wall faults and fracture planes (Reed 1983; Hochstein 1988). Hence, for the Itasy area, the upward migration of fluids is facilitated by steeply dipping NNE strike-slip normal faults. This can explain the presence of hot springs in the northwestern part of the volcanic area (Fig. 4b). Moreover, it is assumed that the NNE-striking faults dip to both the east and west in the Itasy area. The strike-slip faults bounding the pull-apart basin structures dip to the NW and SE, as represented in the cross-section (Fig. 4c). Although an exact recharge area for the thermal water cannot be pinpointed, it is most likely from the surrounding Itasy Mountain Range.

The deep geothermal reservoir is related to fractured Precambrian basement, which may represent the host rocks because no potential units with primary porosity have been found. The basement rocks are migmatitic orthogneiss and paragneiss (Table 3). The average temperature of the geothermal reservoir is estimated by geothermometers to be around 170 to $240{ }^{\circ} \mathrm{C}$ (Gunnlaugsson et al. 1981; Sarazin et al. 1986). Hot spring temperatures range between 24 and $57{ }^{\circ} \mathrm{C}$. These temperatures are lower than the hot springs in the North region.

The heat source is believed to be a fossil magma system since the volcanic activity lasted from 27 to $3 \mathrm{Ma}$ (Bardintzeff et al. 2010; Rufer et al. 2014). This could be related to a recently crystallized magma chamber originating in the lower part of the lithospheric mantle (Bardintzeff et al. 2010), which is situated at $50 \mathrm{~km}$ depth beneath the crust. The latter is less than $40 \mathrm{~km}$ thick (Wysession et al. 2016; Andriampenomanana et al. 2017; Pratt et al. 2017). As in Ambanja and Ambilobe areas, a moderate geothermal gradient is expected.

\section{Antsirabe basin}

The Antsirabe Basin is one of the large Neogene alluvial basins in the highlands occupying a half-graben structure (Fig. 5; Table 2). The extension regime during the Pleistocene created the Manandona and Sahatsio half-grabens (Fig. 5c), delimited by the large Betampona Escarpment and the Mandray Fault, respectively, both of which are westdipping normal faults (Fig. 5b, c). The Antsirabe Basin is dominated by Upper Oligocene to Pleistocene volcanic rocks and extensive flood basalts and trachytes of unknown thickness (Bardintzeff et al. 2010). Most of those originated from the main crest of the Pliocene volcanic massif of Ankaratra (Rufer 2009), and were covered by $25 \mathrm{~m}$ of cinerites and more than $10 \mathrm{~m}$ of Neogene lacustrine sediments (Rasoanimanana et al. 2012). A Precambrian metamorphic basement, which belongs to the Archaean Antananarivo Domain, underlies these formations and consists of orthogneiss migmatite of the Betsiboka suite and granite monzonitic of the Imorona suite.

Water can circulate at depth through fractures in the Precambrian basement, which is assumed to be the host rock (Table 3). The weathered basalt forming arenaceous layers 


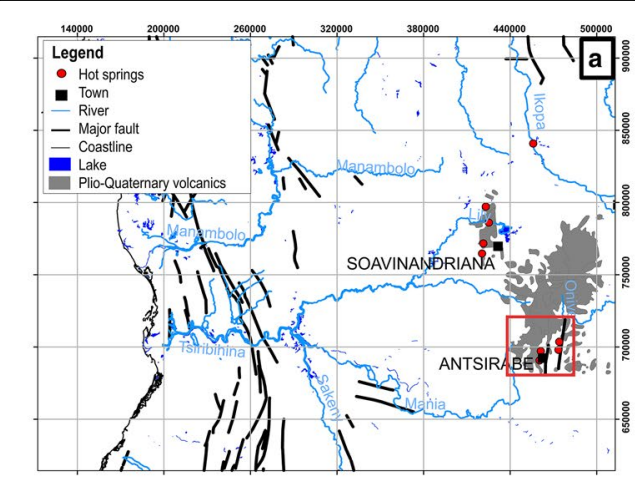

sw

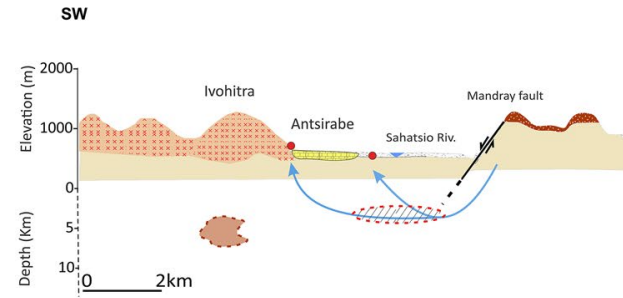

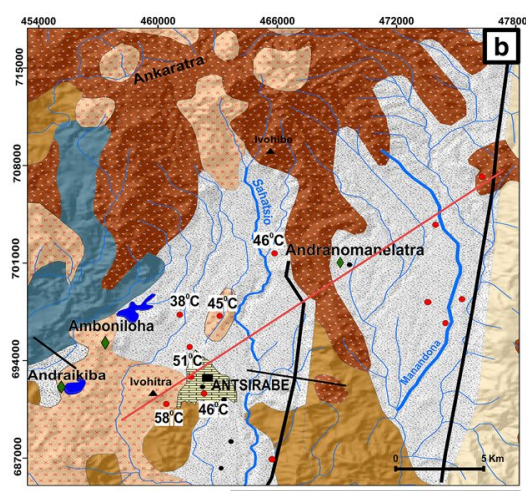

Yic, Potential geothermal reservin

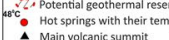

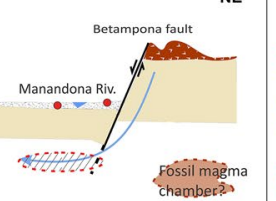
- Town

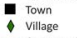
- Cross-section
二 Main river
- Faut
Lake Travertin Volcanics, Neogene
Volcanic ash, cinerte, 19.
Trachyrte, Pleistocenene Basalt, basanite, ankaratritite, Pliocere morona suite, Neoproterozoic
Mononite, undifierentiated syenite

c Granite, orthogneiss
Betsiboka suite, Neoseng

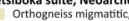

Fig. 5 a Location of the Antsirabe geothermal area, $\mathbf{b}$ detailed geology showing the position of the hot springs, modified from Rufer (2009), and c conceptual model of the Antsirabe Basin geothermal system, adapted from Rasoanimanana et al. (2012). The vertical scale of the elevation profile, which was created using ASTER imagery, has been exaggerated compared to the depth scale, which is based on the structure of the crust and uppermost mantle beneath Madagascar (Andriampenomanana et al. 2017)

is considered to be a permeable formation through which meteoric recharge can occur (Fig. 5b). The deep circulation of underground water is thought to follow the general topography from E to W (Fig. 5c). Normal faults and NE-SW fractures would favour rising fluids, which would explain the presence of hot springs emerging along the Sahatsio Valley and the Antsirabe hot springs, which are aligned in an N-S direction. These hot springs temperatures reach 38 to $57^{\circ} \mathrm{C}$, and the temperature of the geothermal reservoir is estimated to be around 150 to $160{ }^{\circ} \mathrm{C}$, possibly up to $240{ }^{\circ} \mathrm{C}$, according to chemical geothermometers calculated by Gunnlaugsson et al. (1981). However, Sarazin et al. (1986) concluded that the geothermal reservoir temperature should not exceed $150{ }^{\circ} \mathrm{C}$ using a silica geothermometer to estimate temperature since the water of the Antsirabe hot springs has mixed with superficial groundwater.

In the Antsirabe area, the average crustal thickness and lithosphere depth, 40 and $50 \mathrm{~km}$, respectively, are the same as those found in the Itasy area (Wysession et al. 2016; Andriampenomanana et al. 2017; Pratt et al. 2017). As the volcanism is too old (28 to $3 \mathrm{Ma}$ ) to constitute an active heat source, the thermal gradient is expected to be close to or below the moderate range.

\section{West region}

\section{Miandrivazo area}

This area is located in a fault zone marking the contact between the metamorphic basement and the Morondava sedimentary basin (Fig. 6; Table 2). The hot springs are observed from the town of Miandrivazo in the north to the village of Malaimbandy 


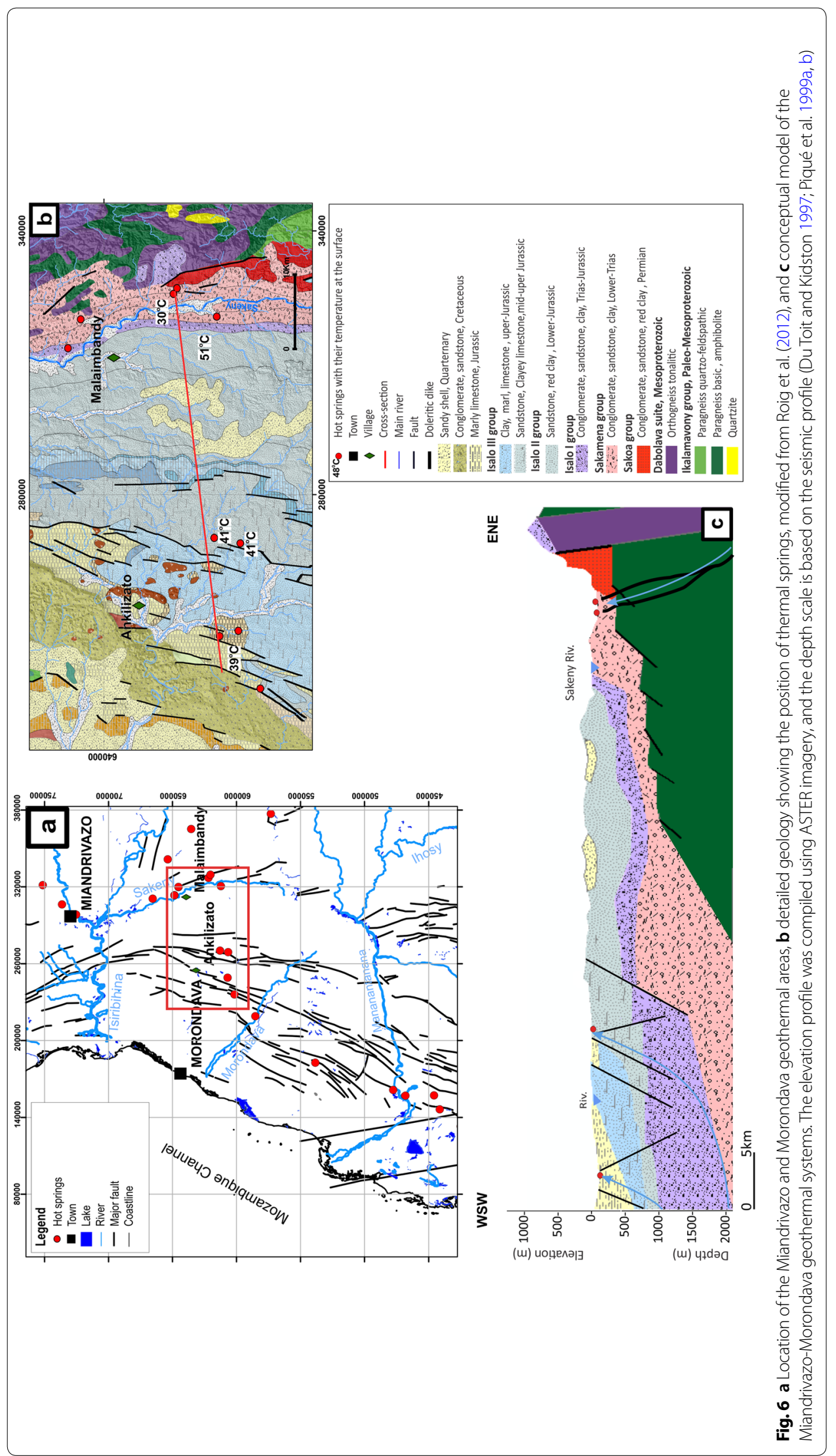


in the south (Fig. 6a). The Proterozoic basement, which is intersected by Cretaceous doleritic dykes, is dominated by tonalitic-granitic orthogneiss of the Dabolava Suite and amphibolite bearing paragneiss belonging to the Ikalamavony Group (Melluso et al. 2001; Tucker et al. 2014). The Karoo sediments in this area are $2 \mathrm{~km}$ thick and consist of conglomerates, sandstones and red clays of the Sakoa Group, and Permian red clay of the Sakamena Group, overlying the basement. Syn-sedimentary normal faults trending N110 E (Piqué et al. 1999a, b) are also observed from Miandrivazo to Malaimbandy (Fig. 6a, b).

The hot springs located near Malaimbandy align in an N-S direction and are observed where doleritic dykes occur (Fig. 6b, c). Fractures in the doleritic dykes are assumed to control the ascent of the thermal water, as proposed by Gunnlaugsson et al. (1981). A local E-W groundwater flow driven by topography was assumed for our conceptual model to explain the hot springs near Malaimbandy (Fig. 6c). Fractured paragneiss and orthogneiss in the basement units are considered potential host rocks since the sedimentary rock cover is relatively thin (Table 3). Hot springs in the area reach 30 to $51{ }^{\circ} \mathrm{C}$ at the surface, and the geothermal reservoir temperature is estimated to be 140 to $170{ }^{\circ} \mathrm{C}$ (Gunnlaugsson et al. 1981).

This region, where the average crustal thickness is estimated to be $36 \mathrm{~km}$, including $3 \mathrm{~km}$ of sedimentary deposits (Andriampenomanana et al. 2017), is an inactive magmatic province since the latest volcanic activity was in the Cretaceous (Melluso et al. 2001). Therefore, the heat source of the area is related to the thin continental crust and the geothermal gradient is expected moderate.

\section{Morondava basin}

The conceptual model for the Morondava Basin was built by combining surface data with seismic profiles (Du Toit and Kidston 1997; Piqué et al. 1999a, b; Geiger et al. 2004), following an WSW-ENE cross-section (Fig. 6c). The Morondava Basin has experienced two main rifting episodes ending with a passive margin evolution (Table 2). The Cretaceous flood basalts and dextral strike-slip faulting affected the sedimentary sequences and were active during the second rifting event, when Madagascar moved southward from Eastern Africa along the Davie Fracture Zone during the Upper Cretaceous (Razafimbelo 1987, Rajaomazava 1992; Piqué et al. 1999a, b; De Wit 2003). This deformation resulted in the small graben and horst structures of the Morondava Basin, created by faults trending N20 $\mathrm{E}$ or $\mathrm{N} 160^{\circ} \mathrm{E}$ (Coffin et al. 1988; Piqué et al. 1999a, b). The ages of the observed continental and marine deposits are Upper Carboniferous to Present. They consist of two main lithostratigraphic units. The first is the Karoo Supergroup sequence (upper-Carboniferous to mid-Jurassic), dominated by continental deposits and subdivided into the Sakoa, Sakamena and Isalo groups, which consist of alternating conglomerates, sandstones, limestones, marls and clays. The second is the Post-Karoo Sequence dated from Upper Jurassic to Lower Cretaceous, consisting essentially of marine deposits (Razafimbelo 1987; Geiger and Schweigert 2006; Reeves 2014). All of the sedimentary units dip to the west and vary from 4 to $6 \mathrm{~km}$ thick on average (Coffin et al. 1988; Piqué et al. 1999a, b; Geiger and Schweigert 2006; Andriampenomanana et al. 2017; Rindraharisaona et al. 2017). 
The topography is flat enough that it is unlikely to drive regional-scale groundwater flow. Hot springs on the western side of the basin are likely explained by saltwater intrusions, their higher density compared to freshwater causing a hydraulic gradient that forces water upward along faults (Fig. 6c). Potential host rocks with primary porosity are the Triassic sandstones and limestones of the Isalo Group (Karoo; Table 3). Aquifers in these formations are already exploited for groundwater at depths between 50 and $82 \mathrm{~m}$ (Mamifarananahary et al. 2007), demonstrating their permeability. The majority of hot springs emerge at the surface of marl, marl-clay or carbonate formations, as observed to the south of Ankilizato village (Fig. 6b, c). Furthermore, a series of NNE-SSW trending faults and fractures that formed during the extension of the basin, which collapsed towards the west, control their distribution (Fig. 6b).

The surface temperatures of springs range from 39 to $42{ }^{\circ} \mathrm{C}$. Geothermometers indicate a reservoir temperature between 120 and $140{ }^{\circ} \mathrm{C}$ (Table 3; Gunnlaugsson et al. 1981), which corresponds to a fluid of low enthalpy. In this area, several oil and gas boreholes have been drilled, and the geothermal gradient has been estimated at $38^{\circ} \mathrm{C} / \mathrm{km}$ (Rider and Kennedy 2011). Therefore, the maximum depth of fluid circulation could be 3 to $4 \mathrm{~km}$.

The average thickness of the crust is very thin in the Morondava Basin, as the Moho is between 18 and $36 \mathrm{~km}$ deep (Andriampenomanana et al. 2017; Rindraharisaona et al. 2017). The thin continental crust is believed to contribute to the higher geothermal gradient.

\section{Discussion}

Developing a complete classification of geothermal systems for Madagascar required a thorough characterization of the dominant geologic controls, geothermal play types and heat sources (Table 2). The information on these features combining with the geothermal characteristics (Table 3) was used to classify the type of system for each geothermal region in this study (Table 4). The conceptual models illustrate a general understanding of the groundwater flow and heat transfer mechanisms affecting the geothermal systems, and they highlight, with an acceptable degree of uncertainty, the factors controlling heat sources, formation permeability and fluid migration. Based on this analysis, the classification can be summarized as follows: (1) geothermal systems in the Morondava area are liquid-dominated, low-temperature systems in a deep sedimentary basin; (2) the Miandrivazo and Ambilobe areas are liquid-dominated, low- to moderate-temperature systems controlled by major boundary faults that delineate the basin-basement contact; (3) the Ambanja, Itasy and Antsirabe areas are liquid-dominated, moderate-temperature systems in a rift setting affecting the basement. Our proposed classification improves the understanding of geothermal systems in Madagascar, which was previously categorized by Andrianaivo (2011) into two types: volcano-tectonic and non-tectonic.

\section{Analogue geothermal systems}

The scarcity of data on the geothermal systems of Madagascar is a sign of the country's early stage of geothermal exploration but can be complemented by studying global 
Table 5 Shared features between Madagascar geothermal areas and global analogues

\begin{tabular}{|c|c|c|c|c|c|}
\hline \multirow{2}{*}{$\begin{array}{l}\text { Region } \\
\text { Area }\end{array}$} & \multicolumn{2}{|l|}{ North } & Central & \multicolumn{2}{|l|}{ West } \\
\hline & Ambilobe & Ambanja & Antsirabe & Miandrivazo & Morondava \\
\hline $\begin{array}{l}\text { Age of volcan- } \\
\text { ism }\end{array}$ & Miocene & \multicolumn{2}{|c|}{ Miocene-Pleistocene } & \multicolumn{2}{|l|}{ Mesozoic } \\
\hline Heat source & Shallow Moho & \multicolumn{2}{|c|}{ Shallow Moho and fossil magma chamber } & \multicolumn{2}{|l|}{ Shallow Moho } \\
\hline Lithology & $\begin{array}{l}\text { Sedimentary } \\
\text { sequences, } \\
\text { magmatic to } \\
\text { metamor- } \\
\text { phic base- } \\
\text { ment }\end{array}$ & $\begin{array}{l}\text { Volcanic rocks } \\
\text { and deposits, } \\
\text { magmatic to } \\
\text { metamor- } \\
\text { phic base- } \\
\text { ment }\end{array}$ & $\begin{array}{l}\text { Neogene deposits, volcanic } \\
\text { rocks, magmatic to meta- } \\
\text { morphic basement }\end{array}$ & \multicolumn{2}{|c|}{$\begin{array}{l}\text { Mesozoic and Permian } \\
\text { sedimentary sequences, } \\
\text { magmatic to metamorphic } \\
\text { basement }\end{array}$} \\
\hline $\begin{array}{l}\text { Structural } \\
\text { setting or } \\
\text { regime }\end{array}$ & $\begin{array}{l}\text { Normal fault- } \\
\text { ing } \\
\text { Dextral/sinis- } \\
\text { tral strike-slip } \\
\text { faults }\end{array}$ & Graben & $\begin{array}{l}\text { Pull-apart } \\
\text { basin }\end{array}$ & $\begin{array}{l}\text { Normal fault- } \\
\text { ing }\end{array}$ & $\begin{array}{l}\text { Horst-graben } \\
\text { structure } \\
\text { in passive } \\
\text { margin } \\
\text { basin }\end{array}$ \\
\hline $\begin{array}{l}\text { Dominant } \\
\text { geologic } \\
\text { control }\end{array}$ & $\begin{array}{l}\text { Quaternary } \\
\text { faulting }\end{array}$ & \multicolumn{2}{|c|}{ Miocene-quaternary active faulting } & \multicolumn{2}{|c|}{ Faults/fractures } \\
\hline Analogue & $\begin{array}{l}\text { Walker Lane, } \\
\text { Great Basin, } \\
\text { USA }\end{array}$ & \multicolumn{2}{|c|}{ Gediz Graben, Western Turkey } & $\begin{array}{l}\text { Walker Lane, } \\
\text { Great Basin, } \\
\text { USA }\end{array}$ & $\begin{array}{l}\text { Main Karoo } \\
\text { Basin, South } \\
\text { Africa }\end{array}$ \\
\hline
\end{tabular}

analogues of geothermal systems at the exploitation stage. Based on geological context, the studied areas in Madagascar share similarities with the northwestern part of the Great Basin in the Basin and Range Province of the USA (Faulds et al. 2010), the Anatolian block of Western Turkey (Yilmazer et al. 2010), and the Main Karoo Basin in South Africa (Campbell et al. 2016), all of which are considered analogues. In terms of geothermal play and geologic controls, all the analogue systems belong to the extensional domain type. In this context, active faulting and fracturing control the permeability necessary for fluid circulation and heat flow conduits, offering a comparable setting with low- to moderate-enthalpy geothermal energy sources. The analogue geothermal systems differ from each other by their respective plate tectonic, geological and structural settings, and heat sources, but each of their characteristics is comparable to the geothermal areas of Madagascar, as summarized in Table 5.

Major geothermal activity occurs in the northwestern part of the Great Basin in the USA, where hydrothermalism is related to transtensional zones and normal faulting, as found in the Walker Lane fault system (Coolbaugh et al. 2005; Faulds et al. 2010). The Ambilobe and Morondava areas in the North and West regions of Madagascar, respectively, share the same characteristics as the Walker Lane geothermal systems, more precisely in the Pyramid Lake fault zone. The latter represents a WNW extensional system, which operates along NW trending lateral strike-slip fault to NNW-striking normal and normal-dextral faults (Faulds et al. 2010). The geothermal system occurs at the intersection between NNW-striking, primarily normal fault, and WNW-striking mainly dextral fault (Faulds et al. 2010). The geological formations are dominated by 1 to $2 \mathrm{~km}$ of mafic Miocene volcanic rocks intercalated with thin sediments, all overlying a Mesozoic granitic to metamorphic basement (Faulds et al. 2010). The nature of the stratigraphic sequences is the main difference between the Great Basin and the Ambilobe and Morondava areas. The volcanic sedimentary rocks in the Basin and Range Province 
are considered the host rocks for the thermal fluids (Moeck 2014), but the fracture and fault setting acts as a major fluid conduit and controls the fluid flow in impermeable formations (Faulds et al. 2010; Wallis et al. 2018). Faulds et al. (2012) also found that the distribution of geothermal reservoirs correlates with areas of higher strain rate. Geothermometry suggests that a deep reservoir at Walker Lane reaches temperatures of 180 to $190{ }^{\circ} \mathrm{C}$ (Faulds et al. 2010), which compares to the range of expected reservoir temperatures in the Ambilobe and Morondava areas (Gunnlaugsson et al. 1981).

E-W-striking normal faults, including major graben-bounding faults, dominate the structural setting in Western Turkey where extensional and transtension zones are active (Faulds et al. 2010, Yilmazer et al. 2010). The Ambanja geothermal area in the Sambirano graben (North region) and the Antsirabe area with half-graben structures (Central region) share similar characteristics with geothermal systems in the Gediz Graben of Western Turkey. The NNE strike-slip faults and pull-apart structures that characterize the Itasy area make the Central region of Madagascar comparable to the geothermal systems of the Marmara region in Turkey where similar NE-SW strike-slip and E-W oblique and normal fault systems have been documented (Simsek 1997). The main geological formations in Western Turkey are dominated by a Paleozoic basement composed of metamorphic rocks (gneiss, mica schist and marble), overlain by Trias-Jurassic to Neogene sedimentary rocks (conglomerate-sandstone and clay units ranging from $50 \mathrm{~m}$ to $6 \mathrm{~km}$ thick), Cenozoic volcanic rocks (Miocene basalt), and finally Quaternary alluvium (Simsek 1997, Yilmazer et al. 2010). Depending on the dominant lithology in the geothermal areas, the cap rock includes clay-rich intervals within the Neogene sedimentary units (Tarcan et al. 2000), and the reservoir lies in basement rocks and/or partially in Miocene basalts (Faulds et al. 2009). These lithologies are similar to those found in the Ambanja, Itasy and Antsirabe area, but the age of the sedimentary deposits and basement rocks are different. The measured reservoir temperature in the Gediz Graben varies from 85 to $215{ }^{\circ} \mathrm{C}$ and decreases from east to west (Yilmazer et al. 2010), which compares to 140 to $240{ }^{\circ} \mathrm{C}$ in the Ambanja, Itasy and Antsirabe areas (Gunnlaugsson et al. 1981).

Geothermal systems in the Morondava Basin in the West region of Madagascar can be compared to those of the Karoo Basin in the Eastern Cape Province of South Africa. The latter is hosted in Permo-Triassic Karoo sedimentary sequences originating from deposits that covered the central part of Gondwana. They are underlain by metamorphic basement rocks of the Namaqua-Natal Belt. Dolerite sills and dykes throughout the Karoo Basin are related to the peak of volcanic activity in South Africa and Lesotho, which was dated at $183 \pm 1 \mathrm{Ma}$ (Campbell et al. 2016). Rock formations in the Morondava Basin are generally expected to have low permeability, similar to the Karoo Basin, except for sandstones representing potential reservoir formations (Campbell et al. 2016). Conductive heat transfer is expected to be the dominant heat transfer mechanism affecting the temperature in the upper crust.

\section{Heat source}

Cenozoic volcanism in northern Madagascar has two assumed origins following the hypotheses advanced by various authors. Michon (2016) proposed that volcanism was 
generated by deformation of the lithosphere, as observed on the volcanic Comoros Island in the context of the southern termination of the East African Rift. Other authors propose a more regional lithospheric extension, allowing local asthenospheric upwelling beneath a thin crust caused by crustal extension and collapse (Wysession et al. 2016; Paul and Eakin 2017; Pratt et al. 2017). The mantle lithosphere is expected to be thin in the volcanic provinces of North and Central Madagascar, as well as in the West Region where Miandrivazo and Morondava geothermal systems are located. Delamination of the lithosphere at its mature stage can even be absent in such extensional zones (Wysession et al. 2016; Pratt et al. 2017), as is the case below the Great Basin in the Western United States (Meissner and Mooney 1998). The average thickness of the Great Basin crust is between 15 and $56 \mathrm{~km}$, whereas the depth of Moho in Turkey varies between 24 and $48 \mathrm{~km}$, and the thinnest crustal thickness $(20-35 \mathrm{~km})$ is found on the western coast of Anatolia (Tezel et al. 2013). According to Faulds et al. (2009, 2010), the main factor causing higher heat flow in the Great Basin, as in Western Turkey, is extensional crustal thinning. This is due to the shallow depth of the Moho, although recent intrusions and/ or volcanism can coincide with extensional zones.

In the Morondava area of Madagascar (West region), where the Moho depth is the shallowest at $18 \mathrm{~km}$ (Andriampenomanana et al. 2017), the heat source is related to crustal thinning. In the Main Karoo Basin, the crust beneath the Mesoproterozoic NamaquaNatal Metamorphic Belt basement has an average thickness of 40-50 km (Delph and Porter 2014). However, this basement is rich in heat-producing elements. The uranium concentration is about 10-54 ppm (Andreoli et al. 2006), which can release heat by the decay of radiogenic elements and affect heat flow (Dhansay et al. 2017).

Geothermal plays can be broadly separated into two types related to the heat transfer mechanism, which is either convection or conduction. Applying the existing catalogue of geothermal play types introduced by Moeck $(2014,2018)$, the geothermal systems of Madagascar are characterized by fault-controlled extensional domains (Table 2) and convection-dominated heat transfer is expected, although conductive heat transfer may occur outside fractured zones.

\section{Fluid origin and flow}

Most thermal spring water in Madagascar is carbon dioxide-rich, dilute $(\mathrm{Cl}<200 \mathrm{ppm})$ and saturated in calcite (Besairie 1959; Gunnlaugsson et al. 1981; Sarazin et al. 1986; Hambinintsoa et al. 2017). The Ambanja, Ambilobe, Itasy and Antsirabe areas, which have the highest estimated reservoir temperatures $\left(140-240{ }^{\circ} \mathrm{C}\right)$, belong to the highcarbonate water type, in which carbonate concentration can be up to $500 \mathrm{ppm}$ (Gunnlaugsson et al. 1981). The high bicarbonate, low chloride composition indicates that thermal fluids have mixed with cooler groundwater or meteoric water as it circulates in upwelling zones along faults (Truesdell 1975). Due to the highly fractured and faulted crustal structures hosting the geothermal systems in Madagascar, there is considerable potential for meteoric water to infiltrate into deeper aquifers and for groundwater to ascend along faults, depending on their dip directions (Reed 1983; Moreno et al. 2018). This is why faults have been assumed to be flow paths in our conceptual models for all six Madagascar geothermal areas (Figs. 2, 3, 4, 5 and 6). Assuming that the geothermal systems have normal to moderate geothermal gradients between 30 and $38{ }^{\circ} \mathrm{C} / \mathrm{km}$ (Rider 
and Kennedy 2011), the fluid sources can be found at depths of 3 to $8 \mathrm{~km}$ considering that the expected reservoir temperature is between 120 and $240{ }^{\circ} \mathrm{C}$ (Gunnlaugsson et al. 1981). Although these estimated temperature ranges have inherent uncertainty because they were produced using chemical thermometers before the advances of Giggenbach's seminal work, the same temperature ranges are obtained when using the Giggenbach diagram based on the chemical composition of the hot springs water as reported in Gunnlaugsson et al. (1981).

The hot springs in the prospective areas of Madagascar are usually located near faults, and the fluid flow appears controlled by tectonic structures. The temperature of the hot springs is likely to decrease at the end of their flow path before reaching the surface, as a result of dilution with cold superficial waters and conduction-convection heat processes (Reed 1983; Ferguson et al. 2009; Moreno et al. 2018). The fluids of geothermal systems in Madagascar are thus related to the deep circulation of meteoric water along faults and fractures, similar to the geothermal systems of the Basin and Range Province where there is no active magmatism (Muffler 1975).

\section{Concluding remarks}

Geothermal areas in Madagascar are commonly associated with extensional domains (Arthaud et al. 1990; Piqué et al. 1999a, b; Andrianaivo and Ramasiarinoro 2010a, b), where major structures such as faults and fractures are the geological controls on fluid flow. Such systems involve heat transfer mechanisms dominated by free convection along the permeable fracture path, whereas heat conduction is likely to occur outside permeable fracture paths. The main source of the heat is crustal thinning, which is locally associated with recently crystallized intrusions, both of which increase the geothermal gradient.

This study categorizes the six main geothermal areas of Madagascar into three distinct classes of geothermal systems: (1) graben bounder-fault liquid-dominated moderatetemperature (Ambilobe and Miandrivazo areas), (2) fossil magmatic liquid-dominated moderate-temperature (Ambanja, Itasy and Antsirabe areas), and (3) sedimentary liquid-dominated low-temperature (Morondava area).

Despite the differences in the overall tectonic setting and geological formations, this classification made it possible to compare the geothermal systems of Madagascar to other typical geologic systems in which geothermal reservoirs have already been discovered and developed. The geothermal systems of the Great Basin (USA), the Anatolian Block (Western Turkey) and the Main Karoo Basin (South Africa) shared similarities with those in Madagascar. This finding has potentially important implications for developing Madagascar's geothermal systems, where geothermal energy sources are associated with secondary porosity features such as fractures.

Conceptual models were constructed for each geothermal area of Madagascar where the geothermal play type provides fundamental knowledge to guide future exploration activities. Such models can be updated when new data become available and constitute a foundation upon which further knowledge can be built. The acquisition of borehole temperature data is the next step to better define heat flow and geothermal energy sources in Madagascar. 
Combining the geothermometer estimates of reservoir temperatures from previous studies with our new classification for geothermal systems, it is possible to envision the production of geothermal electricity in the Ambilobe, Ambanja, Itasy, Antsirabe and Miandrivazo areas, and direct-use geothermal energy projects could be possible for aquaculture, agriculture and cooling in the Morondava area.

\section{Abbreviations}

EGS: Enhanced geothermal system; N-S: North-south; NE-SW: Northeast-southeast; NNW-SSE: North-northwest-southsoutheast; NNE-SSW: North-northeast-south-southwest; USA: United States of America.

\section{Acknowledgements}

The authors would like to thank the Canadian Francophonie Scholarship Program that supported the first author with a scholarship. The UNESCO International Geoscience Program (IGCP) is acknowledged for providing a framework to enhance collaboration amongst members of the IGCP-636 group who are interested in geothermal research and who participated as co-authors. We thank Juliet Newson of the Iceland School of Energy for her helpful discussions and pertinent remarks that improved the conceptual models.

\section{Authors' contributions}

MR worked on data collection and wrote the manuscript. JR and MM directed the project, providing ideas and goals as well as logistical support. CD provided useful comments and insights to improve the conceptual models. All authors proofread the manuscript and provided their comments and insights. All authors read and approved the final manuscript.

\section{Funding}

This project was funded by the Canadian Francophonie Scholarship Program (CFSP-CBIE). Discovery grants from the Natural Sciences and Engineering Research Council of Canada (NSERC) also contributed to this study.

\section{Availability of data and materials}

Data sharing is not possible as no datasets were generated or analyzed during the current study.

\section{Competing interests}

The authors declare that they have no competing interests.

\section{Author details}

${ }^{1}$ INRS-Institut National de la recherche scientifique, 490 de la Couronne, Quebec, QC G1K 9A9, Canada. ${ }^{2}$ BRGM-Bureau de recherches géologiques et minières, 3 Avenue Claude Guillemin, 45100 Orléans, France.

Received: 15 April 2020 Accepted: 13 July 2020

Published online: 28 July 2020

\section{References}

Andreoli MA, Hart RJ, Ashwal LD, Coetzee H. Correlations between U, Th content and metamorphic grade in the western Namaqualand Belt, South Africa, with implications for radioactive heating of the crust. J Petrol. 2006;47:1095-118. Andriampenomanana F, Nyblade AA, Wysession ME, Durrheim RJ, Tilmann F, Julià J, et al. The structure of the crust and uppermost mantle beneath Madagascar. Geophys J Int. 2017;210:1525-44. https://doi.org/10.1093/gji/ggx243.

Andrianaivo L. Caractéristiques générales des systèmes et des régions géothermiques de Madagascar. Madamines. 2011;2:11-21

Andrianaivo L, Ramasiarinoro V. Structural model of the Itasy geothermal prospect in central Madagascar: preliminary review. In: World geothermal congress 2010: 25-29 April Bali, Indonesia. 2010a.

Andrianaivo L, Ramasiarinoro VJ. Relation between regional lineament systems and geological structures: implications for understanding structural controls of geothermal system in the volcanic area of Itasy, Central Madagascar. In: World geothermal congress 2010; 25-29 April, Bali, Indoniesia. 2010b.

Armstead HCH. Geothermal energy: review of research and development. Paris: UNESCO; 1973.

Arthaud F, Grillot J-C, Raunet M. La tectonique cassante à Madagascar: son incidence sur la géomorphologie et sur les écoulements. Can J Earth Sci. 1990;27:1394-407.

Axelsson G. Production capacity of geothermal systems. In: Workshop for decision makers on the direct heating use of geothermal resources in Asia 2008; 11-18 May, Tianjin, China. 2008.

Axelsson G. Conceptual models of geothermal systems-introduction. In: Short course V on conceptual modelling of geothermal systems in El Salvador 2013; February 24-March 2, Santa Tecla, Ahuachapán, Berlín. 2013.

Bardintzeff JM, Liegeois JP, Bonin B, Bellon H, Rasamimanana G. Madagascar volcanic provinces linked to the Gondwana break-up: geochemical and isotopic evidences for contrasting mantle sources. Gondwana Res. 2010;18:295-314 https://doi.org/10.1016/j.gr.2009.11.010.

Bertil D, Marc Regnoult J. Seismotectonics of Madagascar. Tectonophysics. 1998;294:57-74. https://doi.org/10.1016/ S0040-1951(98)00088-2.

Besairie H. Les formations du Karoo à Madagascar. In: Teichert C, editor. Symposium sur les series de Gondwana. Algiers: International Geological Congress; 1952. p. 181-6. 
Besairie H. Contribution à l'étude des sources minérales et des eaux souterraines de Madagascar. Travaux du Bureau Géologique, Service Géologique Antananarivo; Report no.: 92. 1959.

Buchwaldt R. The geology of the neoproterozoic and cenozoic rocks of north Madagascar [PhD thesis]: university of Washington, USA; 2006.

Campbell SA, Lenhardt N, Dippenaar MA, Götz AE. Geothermal energy from the Main Karoo Basin (South Africa): an outcrop analogue study of Permian Sandstone Reservoir Formations. Energy Procedia. 2016;97:186-93. https:// doi.org/10.1016/j.egypro.2016.10.050.

Chorowicz J, Bardintzeff JM, Rasamimanana G, Chotin P, Thouin C, Rudant JP. An approach using SAR ERS images to relate extension fractures to volcanic vents: examples from iceland and Madagascar. Tectonophysics. 1997;271:263-83. https://doi.org/10.1016/S0040-1951(96)00250-8.

Coffin MF, Rabinowitz PD. Evolution of the conjugate East African-Madagascan Margins and the Western Somali Basin, vol. 226. GSA Spec pap. 1988:78. https://doi.org/10.1130/SPE226.

Collins AS. Madagascar and the amalgamation of Central Gondwana. Gondwana Res. 2006;9:3-16.

Coolbaugh MF, Arehart GB, Faulds JE, Garside LJ. Geothermal systems in the Great Basin, western United States: modern analogues to the roles of magmatism, structure, and regional tectonics in the formation of gold deposits. In: Rhoden HN, Steininger RC, Vikre PG, editors. Geological society of Nevada Symposium 2005: window to the World. Reno: Geological Society of Nevada; 2005. p. 1063-81.

Cucciniello C, Tucker R, Jourdan F, Melluso L, Morra V. The age and petrogenesis of alkaline magmatism in the Ampasindava Peninsula and Nosy Be archipelago, northern Madagascar. Miner Petrol. 2016;110:309-31.

De Wit MJ. Madagascar: heads it's a continent, tails it's an island. Annu Rev Earth Planet Sci. 2003;31:213-48. https://doi. org/10.1146/annurev.earth.31.100901.141337.

Delph JR, Porter RC. Crustal structure beneath southern Africa: insight into how tectonic events affect the Mohorovičić discontinuity. Geophys J Int. 2014;200:254-64. https://doi.org/10.1093/gji/ggu376.

Dhansay T, Musekiwa C, Ntholi T, Chevallier L, Cole D, de Wit MJ. South Africa's geothermal energy hotspots inferred from subsurface temperature and geology. S Afr J Sci. 2017;113:1-7.

Dickson MH, Fanelli M. Geothermal energy: utilization and technology. New York: UNESCO; 2003.

Du Toit SR, Kidston AG. The hydrocarbon potential of the East Africa continental margin. Calgary: Alconsult International, Canadian International Development, Agency; 1997.

Erdlac RJ, Jr. A geologic systems-based classification for geothermal energy. In: AAPG/SPE/SEG Hedberg conference; 14-18 March, Napa, California. 2011.

Erdlac RJ Jr, Gross P, McDonald E. A proposed new geothermal power classification system. Geotherm Resour Counc Trans. 2008;32:379-84.

Estrade G. Le complexe cénozoïque alcalin d'Ambohimirahavavy à Madagascar: origine, évolution et minéralisations en métaux rares. Ph.D. Thesis. Toulouse: Universite Toulouse III Paul Sabatier. 2014.

Estrade G, Béziat D, Salvi S, Tiepolo M, Paquette J-L, Rakotovao S. Unusual evolution of silica-under- and -oversaturated alkaline rocks in the Cenozoic Ambohimirahavavy Complex (Madagascar): mineralogical and geochemical evidence. Lithos. 2014;206-207:361-83. https://doi.org/10.1016/j.lithos.2014.08.008.

Falcone G, Antics M, Bayrante L, Conti P, Grant M, Hogarth R, et al. Specifications for the application of the United Nations Framework Classification for fossil energy and mineral reserves and resources 2009 (UNFC 2009) to geothermal energy resources. 2016.

Faulds J, Bouchot V, Moeck IS, Oğuz K. Structural controls of geothermal systems in western Turkey: a preliminary report. Trans Geotherm Resour Counc. 2009;33:375-83.

Faulds J, Coolbaugh M, Bouchot V, Moeck I, Oguz K. Characterizing structural controls of geothermal reservoirs in the Great Basin, USA, and Western Turkey: developing successful exploration strategies in extended terranes. In: World geothermal congress 2010; 25-30 April, Bali, Indonesia. 2010.

Faulds JE, Hinz N, Kreemer C, Coolbaugh M. Regional patterns of geothermal activity in the Great Basin Region. Western USA: correlation with strain rates. 2012;36:897-902.

Ferguson G, Grasby SE, Hindle SR. What do aqueous geothermometers really tell us? Geofluids. 2009;9:39-48. https://doi. org/10.1111/j.1468-8123.2008.00237.x.

Gallup DL. Production engineering in geothermal technology: a review. Geothermics. 2009;38:326-34.

Geiger M, Schweigert G. Toarcian-Kimmeridgian depositional cycles of the south-western Morondava Basin along the rifted continental margin of Madagascar. Facies. 2006;52:85. https://doi.org/10.1007/s10347-005-0039-8.

Geiger M, Clark DN, Mette W. Reappraisal of the timing of the breakup of Gondwana based on sedimentological and seismic evidence from the Morondava Basin, Madagascar. J Afr Earth Sci. 2004;38:363-81.

Giese J, Berger A, Schreurs G, Gnos E. The timing of the tectono-metamorphic evolution at the Neoproterozoic-Phanerozoic boundary in central southern Madagascar. Precambrian Res. 2011;185:131-48. https://doi.org/10.1016/j.preca mres.2011.01.002

Gunnlaugsson E, Arnorsson S, Matthiasson M. Madagascar-reconnaissance survey for geothermal resources. Report, Projet MAG/77/104, Contract 141/79, VIRKIR. 1981.

Hambinintsoa RAH, Ranaivoarisoa A, Blessent D. Hydrogeochemical characterization of thermomineral waters in the central highlands of madagascar. In: UNESCO IGCP636 2017; 20-24 November, Santiago, Chile. 2017.

Hinz N, Coolbaugh M, Shevenell L, Stelling P, Melosh G, Cumming W. Favorable structural-tectonic settings and characteristics of globally productive arcs. In: 41st workshop on geothermal reservoir engineering 2016; 22-24 February Stanford University, Stanford, California. 2016

Hochstein MP. Assessment and modelling of geothermal reservoirs (small utilization schemes). Geothermics. 1988;17:1549. https://doi.org/10.1016/0375-6505(88)90004-1.

Hochstein MP. Classification and assessment of geothermal resources. In: Dickson Mary H, Fanelli M, editors. Small geothermal resources: a guide to development and utilization. New York: UNITAR; 1990. p. 31-57.

Lardeaux JM, Martelat JE, Nicollet C, Pili E, Rakotondrazafy R, Cardon H. Metamorphism and tectonics in Southern Madagascar: an overview. Gondwana Res. 1999;2:355-62. https://doi.org/10.1016/S1342-937X(05)70274-4. 
Lee KC. Classification of geothermal resources by exergy. Geothermics. 2001;30:431-42. https://doi.org/10.1016/S0375 $-6505(00) 00056-0$

Mamifarananahary E, Rajaobelison J, Ramaroson V, Rahobisoa J. Groundwater recharge process in the Morondava sedimentary Basin, Southwestern Madagascar. In: 3rd HEP MAD'07 international conference 2007; 10-15 September, Antananarivo, Madagascar. 2007.

McCoy-West AJ, Milicich S, Robinson T, Bignall G, Harvey CC. Geothermal resources in the Pacific Islands: the potential of power generation to benefit indigenous communities. In: 36th workshop on geothermal reservoir engineering 2011; January 31-February 2, Stanford University, Stanford, California. 2011.

Meissner R, Mooney W. Weakness of the lower continental crust: a condition for delamination, uplift, and escape. Tectonophysics. 1998;296:47-60. https://doi.org/10.1016/S0040-1951(98)00136-X.

Melluso L, Morra V. Petrogenesis of Late Cenozoic mafic alkaline rocks of the Nosy Be archipelago (northern Madagascar): relationships with the Comorean magmatism. J Volcanol Geotherm Res. 2000;96:129-42.

Melluso L, Morra V, Brotzu P, Mahoney J. The cretaceous igneous province of Madagascar: geochemistry and Petrogenesis of Lavas and Dykes from the Central-Western Sector. J Petrol. 2001. https://doi.org/10.1093/petrology/42.7.1249.

Michon L. The volcanism of the Comoros archipelago integrated at a regional scale. In: Bachèlery P, Lénat J-F, Di Muro A, Michon L, editors. Active volcanoes of the Southwest Indian Ocean: Piton de la Fournaise and Karthala. Heidelberg: Springer; 2016. p. 333-44.

Moeck IS. Catalog of geothermal play types based on geologic controls. Renew Sustain Energy Rev. 2014;37:867-82. https://doi.org/10.1016/j.rser.2014.05.032.

Moeck IS. Geothermal plays, geological analogs, resources assessment, exploration chance, risk evaluation. In: 12th Asian geothermal symposium; 10-12 November 2018, Daejeon, Korea. 2018.

Moeck IS, Beardsmore Graeme CHC. Cataloging worldwide developed geothermal systems by geothermal play type. In: World geothermal congress; 19-25 April, Melbourne, Australia. 2015.

Moeck IS, Dussel M, Weber J, Schintgen T, Wolfgramm M. Geothermal play typing in Germany, case study Molasse Basin: a modern concept to categorise geothermal resources related to crustal permeability. Neth J Geosci. 2019;98:e14. https://doi.org/10.1017/njg.2019.12.

Moreno D, Lopez-Sanchez J, Blessent D, Raymond J. Fault characterization and heat-transfer modeling to the Northwest of Nevado del Ruiz Volcano. J S Am Earth Sci. 2018;88:50-63. https://doi.org/10.1016/j.jsames.2018.08.008.

Mottet G. Tectonique et volcanisme dans le massif du Tsaratanana-Ankaizina (Nord de Madagascar). Bull de l'Association de Géographes Français. 1982. https://doi.org/10.3406/bagf.1982.5323.

Muffler P. Tectonic and hydrologic control of the nature and distribution of geothermal resources. In: 2nd U.N. symposium on the development and use of geothermal resource 1975; 20-29 May, San Fransisco, California. 1975.

Muffler P, Cataldi R. Methods for regional assessment of geothermal resources. Geothermics. 1978;7:53-89. https://doi. org/10.1016/0375-6505(78)90002-0.

Nicholson K. Geothermal fluids. Berlin: Springer; 1993.

Paul JD, Eakin C. Mantle upwelling beneath Madagascar: evidence from receiver function analysis and shear wave splitting. J Seismol. 2017. https://doi.org/10.1007/s10950-016-9637-x.

Piqué A, Laville E, Bignot G, Rabarimanana M, Thouin C. The initiation and development of the Morondava Basin [Madagascar] from the late carboniferous to the Middle Jurassic: sedimentary, palaeontological and structural data. J Afr Earth Sci. 1999a;28:931-48. https://doi.org/10.1016/S0899-5362(99)00070-6.

Piqué A, Laville E, Chotin P, Chorowicz J, Rakotondraompiana S, Thouin C. L'extension à Madagascar du Néogène à I'Actuel: arguments structuraux et géophysiques. J Afr Earth Sci. 1999b;28:975-83. https://doi.org/10.1016/S0899 $-5362(99) 00073-1$.

Pratt MJ, Wysession ME, Aleqabi G, Wiens DA, Nyblade AA, Shore P, et al. Shear velocity structure of the crust and upper mantle of Madagascar derived from surface wave tomography. Earth Planet Sci Lett. 2017;458:405-17.

Rajaomazava. Élude de la subsidence du bassin sédimentaire de Morondava (Madagascar) dans le cadre de l'évolution géodynamique de la marge est-africaine. Ph.D Thesis. Montpelier: Université des Sciences et Techniques du Languedoc. 1992.

Rakotondrainibe. Contribution à l'étude de la séismicité à Madagascar. Ph.D Thesis. Antananarivo: Université d'Antananarivo. 1977.

Ramarolahy RA. Etude du mécanisme au foyer de la zone volcanique d'Itasy: Sismologie: Editions universitaires europeennes EUE; 2016.

Rasamimanana G. Caractérisation géochimiques et géochronologiques de trois épisodes magmatiques (Crétace', Miocène terminal et Quaternaire) à Madagascar, associés aux phénomènes de rifting. Ph.D Thesis. Orsay: Université Paris-Sud. 1996.

Rasamimanana G, Bardintzeff J-M, Rasendrasoa J, Bellon H, Thouin C, Gioan P, et al. Les épisodes magmatiques du SudOuest de Madagascar (bassin de Morondava), marqueurs des phénomènes de rifting crétacé et néogène. $C R$ Acad Sc II A. 1998;326:685-91. https://doi.org/10.1016/S1251-8050(98)80179-1.

Rasoanimanana RR, Nicoud G, Mietton M, Paillet A. Réinterprétation des formations superficielles pléistocènes du bassin d'Antsirabe (Hautes Terres Centrales de Madagascar). Quaternaire. 2012;23:339-53. https://doi.org/10.4000/quate rnaire.6431.

Ratsimbazafy. JB, A., Éléments structuraux acquis par géophysique (méthodes magnétique et magnétotellurique) dans la région volcanique de l'itasy (centre de Madagascar). Ph.D Thesis. Antananarivo: Observatoire d'Antananarivo. 1987.

Razafimbelo E. Le bassin de morondava (Madagascar): synthèse géologique et structurale. Ph.D Thesis. Strasbourg: Université Louis Pasteur. 1987.

Reed MJ. Assessment of low-temperature geothermal resources of the United States-1982. Circular 892, USGS. 1983.

Reeves C. The position of Madagascar within Gondwana and its movements during Gondwana dispersal. J Afr Earth Sci. 2014;94:45-57. https://doi.org/10.1016/j.jafrearsci.2013.07.011.

Rezaie M, Aghajani H. A new combinational terminology for geothermal systems. Int J Geosci. 2013;4:43-8. https://doi. org/10.4236/ijg.2013.41005.

Rider M, Kennedy M. The geological interpretation of well logs. 3rd ed. Scotland: Rider-French; 2011. 
Rindraharisaona EJ, Guidarelli M, Aoudia A, Rambolamanana G. Earth structure and instrumental seismicity of Madagascar: implications on the seismotectonics. Tectonophysics. 2013;594:165-81. https://doi.org/10.1016/j.tecto .2013.03.033.

Rindraharisaona EJ, Tilmann F, Yuan X, Rumpker G, Giese J, Rambolamanana G, et al. Crustal structure of southern Madagascar from receiver functions and ambient noise correlation: implications for crustal evolution. J Geophys Res Solid Earth. 2017;122:1179-97. https://doi.org/10.1002/2016JB013565.

Roberts GG, Paul JD, White N, Winterbourne J. Temporal and spatial evolution of dynamic support from river profiles: a framework for Madagascar. Geochem Geophys Geosyst. 2012;13:1-23.

Roig JY, Tucker RD, Delor C, Peters SG, Théveniaut H, cartographers. Carte géologique de la Répulique de Madagascar à 1/1000000: Ministère des Mines, PGRM, Antananarivo, République Madagascar. 2012.

Rossi G. Quelques aspects d'une haute montagne tropicale: le massif du Tsaratanana (Madagascar). Revue de Géographie Alpine. 1980;68:153-72. https://doi.org/10.3406/rga.1980.1014.

Rufer D. Characterization and age determination of quaternary volcanism in the southern Ankaratra region (central Madagascar) through novel approaches in luminescence dating. Ph.D Thesis. Bern: University of Bern. 2009.

Rufer D, Guido S, Alfons B, Edwin G, Igor V. Cenozoic alkaline volcanism in central Madagascar in the context of intracontinental rifting. In: Abstract of 4th Swiss geoscience meeting; 24-25 November, Bern, Switzerland. 2006.

Rufer D, Preusser F, Gnos E, Schreurs G, Berger A. Late Quaternary volcanic history of the Vakinankaratra volcanic field (central Madagascar): insights from luminescence dating of phreatic eruptions. Bull Volcanol. 2014;76:65. https:// doi.org/10.1007/s00445-014-0817-7.

Sanyal SK. Classification of geothermal systems-a possible scheme. In: 30th workshop on geothermal reservoir engineering 2005; January 31-February 2, Stanford University, Stanford, California. 2005.

Sarazin G, Michard G, Pastor L. Geochemical study of the geothermal field of Antsirabe (Madagascar). Geochem J. $1986 ; 20: 41-50$.

Sass I, Götz AE. Geothermal reservoir characterization: a thermofacies concept. Terra Nova. 2012;24:142-7. https://doi.org /10.1111/j.1365-3121.2011.01048.x.

Schintgen TV, Wuttke MW, Agemar T, Moeck IS. Refinement of the geothermal play type concept by comparison of two foreland basins. In: European geothermal congress; 11-14 June, Den Haag, The Netherlands. 2019.

Simsek S. Geothermal potential in northwestern Turkey. In: Schindler C, Martin P, editors. Active tectonics of Northwestern Anatolia: the marmara poly-project : a multidisciplinary approach by space-geodesy, geology, hydrogeology, geothermics and seismology. Zurich: Vdfhochschulverlag AG ander ETH; 1997. p. 111-24.

Tarcan G, Filiz S, Gemici U. Geology and geochemistry of the Salihli geothermal fields, Turkey. In: World geothermal congress 2000; May 28-June 10, Kyushu Tohoku Japan. 2000.

Tezel T, Shibutani T, Kaypak B. Crustal thickness of Turkey determined by receiver function. J Asian Earth Sci. 2013;75:36-45.

Thomas B, Waele B, Schofield DI, Goodenough K, Horstwood M, Tucker R, et al. Geological evolution of the Neoproterozoic Bemarivo Belt, northern Madagascar. Precambrian Res. 2009;172:279-300. https://doi.org/10.1016/j.preca mres.2009.04.008.

Truesdell AH. Summary of section III: geochemical techniques in exploration. In: Second United Nations symposium on the development and use of geothermal resources 1975; 20-29 May, San Francisco, California. 1975.

Tucker R, Roig JY, Moine B, Delor C, Peters SG. A geological synthesis of the Precambrian shield in Madagascar. J Afr Earth Sci. 2014;94:9-30. https://doi.org/10.1016/j.jafrearsci.2014.02.001.

Wallis IC, Rowland JV, Dempsey D. The relationship between geothermal fluid flow and geologic context: a global review. Geotherm Resour Counc Trans. 2018;42:1-19.

White DE. Characteristics of geothermal resources. 1973:69-94

Williams CF, Reed MJ, Anderson AF. Updating the classification of geothermal resources. In: 36th workshop on geothermal reservoir engineering 2011; January 31-February 2, 2011, Stanford University, Stanford, California. 2011.

Windley BF, Razafiniparany A, Razakamanana T, Ackermand D. Tectonic framework of the Precambrian of Madagascar and its Gondwana connections: a review and reappraisal. Geol Rundsch. 1994;83:642-59. https://doi.org/10.1007/ BF00194168.

Wysession M, Pratt M, Andriampenomanana Ny Ony F, Tsiriandrimanana R, Nyblade A, Aleqabi G, et al. The lithospheric structure of madagascar. In: AGU fall meeting abstracts 2016; 12-16 December, San Fransisco, California. 2016.

Yilmazer S, Pasvanoğlu S, Vural S. The relation of geothermal resources with young tectonics in the Gediz graben (West Anatolia, Turkey) and their hydrogeochemical analyses. In: World geothermal congress 2010; 25-29 April, Bali, Indonesia. 2010.

\section{Publisher's Note}

Springer Nature remains neutral with regard to jurisdictional claims in published maps and institutional affiliations. 